\title{
The Implementation \& Sustainment Facilitation Strategy improved implementation effectiveness and intervention effectiveness: Results from a cluster-randomized type 2 hybrid trial
}

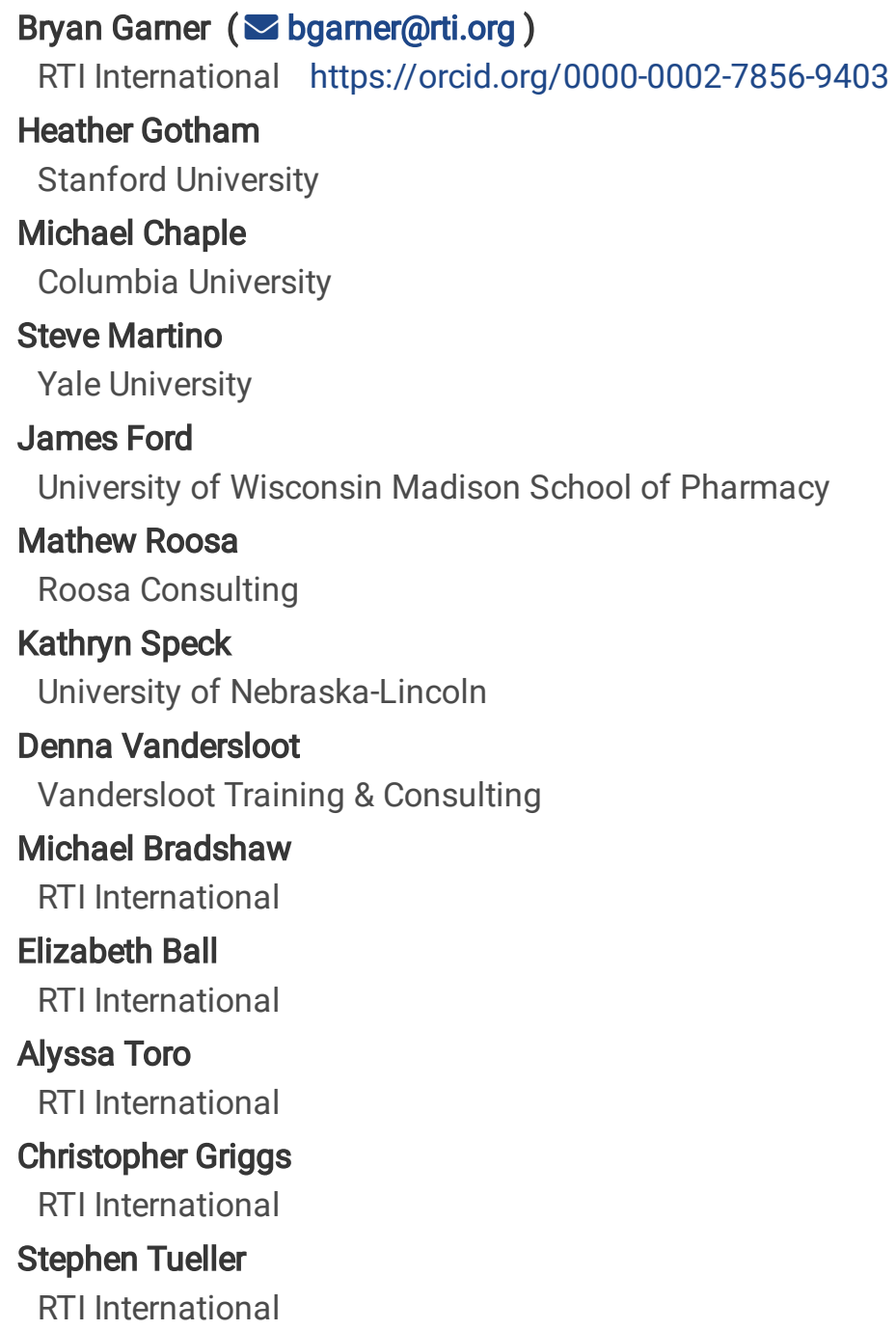

Research

Keywords: Implementation Strategies, External Facilitation, Substance Use, Addiction Technology Transfer Center, Motivational Interviewing, HIV

Posted Date: March 30th, 2020

DOI: https://doi.org/10.21203/rs.3.rs-19843/v1

License: (c) (i) This work is licensed under a Creative Commons Attribution 4.0 International License. Read Full License 
Version of Record: A version of this preprint was published at Implementation Research and Practice on January 1st, 2020. See the published version at https://doi.org/10.1177/2633489520948073. 


\section{Abstract}

Background Substance use disorders (SUD) among people with HIV are both prevalent and problematic. In 2014, the Substance Abuse Treatment to HIV care (SAT2HIV) Project was funded to test the team-focused Implementation \& Sustainment Facilitation (ISF) strategy as an adjunct to the staff-focused Addiction Technology Transfer Center (ATTC) strategy for integrating a motivational interviewing-based brief intervention (MIBI) for SUD within HIV community-based organizations (CBOs). This article presents the main findings from the project.

Methods Using a cluster-randomized, type 2 hybrid trial design, 39 HIV-CBOs were randomized to either: 1) ATTC $(n=19)$; or 2) ATTC+ISF $(n=20)$. HIV-CBOs identified two staff to be prepared to implement the MIBI ( $N=78$ MIBI staff). Subsequently, during the implementation phase, HIV-CBOs in each condition randomized client participants ( $\mathrm{N}=824$ client participants) to one of two intervention conditions: 1) usual care (UC; $n=415)$; or 2) UC+MIBI ( $n=409)$. Both staff-level outcomes and clientlevel outcomes were examined.

Results The ISF strategy had a significant impact on implementation effectiveness (i.e., the consistency and quality of implementation; $\beta=0.65, p=01)$, but not on time-to-proficiency $(\beta=-0.02)$ or level-of-sustainment $(\beta=0.09)$. Additionally, the ISF strategy was found to have a significant impact on intervention effectiveness (i.e., the effectiveness of the MIBI), at least in terms of significantly decreasing the odds (odds ratio $=0.11, p=.02$ ) of clients using their primary substance daily during follow-up.

Conclusions The ATTC strategy was sufficient for the preparation of HIV-CBO staff to implement a MIBI for SUDs, yet the ISF strategy was found to be an effective adjunct to the ATTC strategy in terms of implementation effectiveness and intervention effectiveness. Based on these findings, it is recommended future efforts to integrate the project's MIBI for SUD within HIV-CBOs use the ATTC+ISF strategy. However, given the ISF strategy did not have a significant impact on level-of-sustainment, which was similarly low in both implementation conditions, implementation research testing the extent to which the ATTC+ISF strategy can be significantly enhanced via effective sustainment strategies is warranted.

\section{Background}

Substance use among people with HIV (PWH) is a significant public health issue given it has been found to be associated with increased psychiatric problems (1), poorer HIV viral suppression (2-4), poorer HIV medication adherence (5-8), and increased likelihood of engaging in risk behaviors that result in infection transmission to others (9-11). Increasing its public health significance further, research suggests approximately half of PWH have a substance use disorder (SUD) (12).

Complementing HIV primary care, HIV community-based organizations (CBOs) provide medical and nonmedical case management services (e.g., retention in care, medication adherence, referral to social services and specialty treatment) and are a major source of care for PWH (13). Thus, in 2014, as part of its multipronged effort to help improve the integration of substance use services within HIV service settings, the National Institute on Drug Abuse (NIDA) funded the Substance Abuse Treatment to HIV care (SAT2HIV) Project to help advance generalizable knowledge about how best to integrate SUD services within HIV-CBOs across the United States. The primary aim of the SAT2HIV Project was to test the team-focused Implementation \& Sustainment Facilitation (ISF) strategy as an adjunct to the staff-focused Addiction Technology Transfer Center (ATTC) strategy for helping HIV-CBOs and their staff integrate a motivational interviewing-based brief intervention (MIBI) for SUDs (14). However, given the importance of context $(15,16)$ and given research on the effectiveness of MIBIs for SUDs with HIV settings was relatively limited (17-19), the SAT2HIV Project also examined the impact of the ISF strategy on intervention effectiveness (i.e., the effectiveness of the MIBI on improving client-level outcomes (20-24). Written in accordance with both the Consolidated Standards of Reporting Trials (CONSORT) guidelines for cluster-randomized trials (25) (see Additional File 1 for checklist) and the Standards for Reporting Implementation Studies (StaRI) guidelines (26) (see Additional File 2 for checklist), this article presents the main findings from the SAT2HIV Project.

Rationale for Trial Design

Page 3/31 
Consistent with the primary objective of NIDA's funding opportunity (27), the SAT2HIV Project's primary aim was to test the team-focused ISF strategy as an effective adjunct to the staff-focused ATTC strategy for helping integrate a MIBI for SUDs within HIV-CBOs. We used a cluster-randomized design (HIV-CBOs were the unit of randomization) to minimize the likelihood of contamination across the project's two implementation conditions and because cluster-randomized designs had been noted as being preferred over other designs, including stepped-wedge designs (28-30). However, beyond the use of a clusterrandomized design, we used a type 2 hybrid trial design given Curran et al.'s (31) recommendation of it as an innovative design "in support of more rapid translation" and to "provide more valid estimates of potential clinical effectiveness." Recently, Landes et al. (32) highlighted the SAT2HIV Project as a "dual-randomized trial" and noted it as a "rarer" type 2 trial design. However, given that randomization was sequential (i.e., HIV-CBOs and their staff randomized during the preparation phase; HIV-CBO client participants randomized within HIV-CBOs during the project's implementation phase), the SAT2HIV Project may also be considered a type of sequential multiple assignment randomized trial (33) or a multilevel $2 \times 2$ factorial trial (34).

Rationale for Testing a MIBI for SUDs as an Adjunct to Usual Care Within HIV-CBOs

As highlighted by DiClemente et al. (35), multiple reviews have supported the efficacy and effectiveness of MIBIs for reducing alcohol use (36-39) and cannabis use (37, 40-42). However, supporting our rationale for integrating a MIBI for SUDs within HIV service settings was research conducted within HIV service settings and found MIBIs can be effective for reducing alcohol use $(17,19)$ and the use of other substances $(18)$.

To help maximize the external validity of the project and its findings, we aimed to examine the effectiveness of the project's MIBI for SUD as an adjunct to usual care (UC) within HIV-CBO (i.e., UC + MIBI compared to UC only). Regarding UC within HIV$\mathrm{CBOs}$, we found standardized substance use screening was rare, with it being even rarer for HIV-CBOs to employ staff adequately trained to address substance SUDs. Rather, we found UC for SUDs within HIV-CBOs was primarily referral to treatment. Thus, although most HIV-CBOs could possibly be considered as implementing the last component of screening, brief intervention, and referral to treatment (SBIRT), there was a clear need for research to identify effective strategies for helping HIV-CBOs integrate the brief intervention component of SBIRT.

\section{Rationale for Testing the ISF Strategy as an Adjunct to the ATTC Strategy}

The combination of staff training, performance feedback, and coaching has been found to be one of the most effective strategies for helping prepare individuals to implement motivational interviewing-based interventions with proficiency (43-49). The ATTC Network (50), which is one of the oldest and largest intermediary/purveyor organizations in the United States (51), has long used this multifaceted strategy to help addiction treatment organizations improve the integration of motivational interviewing for SUDs. As such, the ATTC strategy was identified as one of the most promising strategies for helping HIV-CBOs and their staff integrate the project's MIBI. However, given implementation and sustainment are acknowledged as multilevel processes $(16,52)$, the staff-focused ATTC strategy was hypothesized to be a necessary, but not sufficient, strategy (14). Thus, building upon research that identified facilitation (i.e., process of interactive problem solving and support that occurs in a context of a recognized need for improvement and a supportive interpersonal relationship) as a promising strategy (53-63), we aimed to test the team-focused ISF strategy as an effective adjunct to the staff-focused ATTC strategy (14).

As detailed by Garner et al. (14) the ISF strategy is a multifaceted strategy with facilitation as the overarching discrete strategy, encompassing six additional discrete strategies (i.e., develop tools for quality improvement; organize implementation team meetings; identify and prepare champions; assess for readiness and identify barriers; conduct local consensus discussions; conduct cyclical small tests of change). Grounded in the theory of implementation effectiveness (20-23), the ISF strategy seeks to improve implementation effectiveness (i.e., the consistency and quality of implementation of the clinical intervention) and intervention effectiveness (i.e., the clinical intervention's effectiveness in terms of improving client outcomes) via improving implementation climate (i.e., the extent to which implementation is expected, supported, and rewarded). However, guided by the Exploration-Preparation-Implementation-Sustainment (EPIS) framework (16), we sought to expand the theory of implementation effectiveness in two ways. Specifically, by examining the extent to which the ISF strategy would help decrease staff time-to-proficiency (the project's preparation phase outcome) and increase staff level-of-sustainment (the project's 
sustainment phase outcome) (14). In addition to being grounded in the theory of implementation effectiveness, the ISF strategy was grounded in motivational interviewing principles (64), which is similar to how Kauth et al. (56) employed motivational interviewing techniques as part of their multifaceted facilitation strategy for improving implementation of cognitive behavioral therapy within 20 Department of Veteran Affairs clinics. Thus, as part of each ISF strategy meeting, the ISF facilitator attempts to: (1) engage the implementation team, (2) help focus the implementation team on the project's key goal(s), (3) help evoke from the implementation team pros and cons related to the project's key goal(s), and (4) help the implementation team plan how best to achieve the project's key goals and sustain those achievements over time.

Primary Aims and Hypotheses

The primary aim of the SAT2HIV Project was to test the ISF strategy as an effective adjunct to the ATTC strategy for helping HIV-CBOs and their staff integrate a MIBI for SUDs. Guided by the theory of implementation effectiveness (20-23) and the EPIS framework (16), we hypothesized that the ISF strategy would have significant impacts on three staff-level outcome measures (i.e., decreasing time-to-proficiency, increasing implementation effectiveness, and increasing level-of-sustainment; see Fig. 1). However, as detailed by MacKinnon (65) integrating moderators into research design is important to understand generalizability by examining the extent to which there are any differential effects that would impede interpretation of a main effect. Thus, we further hypothesized (see Fig. 1) that the impact of the ISF strategy on these staff-level outcomes would be moderated by components of the Consolidated Framework for Implementation Research's (CFIR) (15) inner setting domain (i.e., implementation readiness, implementation climate, leadership engagement, tension-for-change) and characteristics of individuals domain (i.e., motivational interviewing experience, personal recovery status). Guided by implementation effectiveness theory (20-23) and Curran et al.'s suggestions regarding advantages of type 2 hybrid trials (31), we also hypothesized (see Fig. 1) that the ISF strategy would impact (i.e., moderate) the effectiveness of the MIBI (i.e., intervention effectiveness) in terms of improving client outcomes (e.g., decreasing days of primary substance use, decreasing times engaging in risky behaviors, decreasing days of missed HIV medication).

\section{Methods}

Trial Design

The trial design was a cluster-randomized, type 2 hybrid trial. Following an exploration phase in which HIV-CBOs were recruited, HIV-CBOs (and their staff) were randomized to one of two strategies: 1) the ATTC strategy; or 2) the ATTC + ISF strategy. Following randomization, the trial was deployed using a multiphase design that included three 6-month phases corresponding to the preparation, implementation, and sustainment phases of the EPIS framework (16). During the implementation phase, HIV-CBOs recruited and randomized client participants to one of two clinical intervention conditions: 1) $\mathrm{UC}$, or 2) UC+ MIBI. Institutional review board (IRB) approval and oversight of all research activities were provided by RTI International's IRB.

Context

HIV-CBOs, located in 23 states and the District of Columbia within the United States, provided the context for the SAT2HIV Project.

Participants

HIV-CBO staff participants. To be eligible to participate, an HIV-CBO was required to: (a) serve a minimum of 100 individuals living with HIV per year; (b) have at least two staff willing and able to be prepared to implement a MIBI for SUDs; and (c) have at least one leadership staff (e.g., supervisor, manager, director) willing to help ensure MIBI staff were given sufficient time to participate. There were no exclusion criteria. Each collaborating HIV-CBO identified two staff to be prepared to implement the $\mathrm{MIBI}$ as part of the project's implementation phase and to be recruited for participation in staff surveys. Each HIV-CBO also identified 1-3 leadership staff to be recruited for participation in staff surveys. Staff completed surveys prior to randomization 
(i.e., before the preparation phase), after the implementation phase (month 13), and after the sustainment phase (month 19), and received a \$25 e-gift card per survey. For more details, see the study protocol paper (14).

HIV-CBO client participants. Client eligibility was assessed by HIV-CBO staff via the project's standardized screener. Eligibility criteria included: (a) having been diagnosed with HIV; (b) being 18 + years of age; and (c) acknowledging use of at least one substance in the past 28 days with self-reported endorsement of two or more of the 11 Diagnostic and Statistical Manual of Mental Disorders (DSM-5) criteria (66) for SUD for that substance during the past 12 months. An exclusion criterion was not being able to speak English, which was due to the project's research staff and MIBI proficiency raters being monolingual.

Clients who met eligibility criteria were recruited for study participation by one of several trained HIV-CBO staff. However, it was one of the two MIBI staff from each HIV-CBO who was trained to administer the baseline assessment, follow-up locator form, and open the randomization envelope with client participants. Each HIV-CBO was provided compensation to cover staff time to complete these research-related activities. Clients randomized to the UC + MIBI condition received the MIBI at no cost. Clients received a $\$ 20$ gift card for completing the baseline assessment, as well as $\$ 20$ for completing a 4-week follow-up assessment administered by research staff blinded to all condition assignments.

Implementation Strategies

Complementing the comprehensive descriptions provided as part of our study protocol paper (14), Table 1 highlights: (a) the 10 discrete strategies in the ATTC strategy, (b) the 7 discrete strategies in the ISF strategy, and (c) the phase that each strategy was made available. For the ATTC strategy, the HIV-CBO's two MIBI staff were given the opportunity to receive 12 months of MIBI training and technical assistance: (a) training (5-hour online didactics, 2-day in-person workshop), (b) performance feedback (standardized feedback on 1-3 MIBIs during the preparation phase, standardized feedback on all MIBIs during the implementation phase), and (c) consultation (1-2 individual consultation calls during the preparation phase, monthly 1-hour group consultation calls during the implementation phase). For the ISF strategy, the HIV-CBO's MIBI staff and leadership staff were given the opportunity to additionally receive 18 months of external facilitation led by one of the project's ISF facilitators (monthly virtual team meetings lasting 30-60 minutes, 1-2 in-person meetings lasting approximately 4 hours). To maximize the extent to which the ISF strategy was implemented with consistency and quality, the project's lead developer of the ISF strategy (BG) trained each ISF facilitator, reviewed randomly selected ISF session recordings (each virtual ISF facilitation meeting was video recorded for quality assurance purposes), and regularly supervised the ISF facilitators (no less than monthly, usually weekly). For more details see the study protocol paper (14). 
Table 1

Discrete Strategies Included Within the ATTC Strategy and the ISF Strategy

\begin{tabular}{|c|c|c|c|c|}
\hline & Discrete Strategies & $\begin{array}{l}\text { Preparation } \\
\text { Phase }\end{array}$ & $\begin{array}{l}\text { Implementation } \\
\text { Phase }\end{array}$ & $\begin{array}{l}\text { Sustainment } \\
\text { Phase }\end{array}$ \\
\hline \multirow{10}{*}{$\begin{array}{l}\text { ATTC } \\
\text { Strategy }\end{array}$} & Centralized technical assistance & $\checkmark$ & $\checkmark$ & \\
\hline & Develop educational materials & $\checkmark$ & & \\
\hline & $\begin{array}{l}\text { Develop and organize quality monitoring } \\
\text { system }\end{array}$ & $\checkmark$ & & \\
\hline & Develop tools for quality monitoring & $\checkmark$ & & \\
\hline & Distribute educational materials & $\checkmark$ & & \\
\hline & Conduct educational meetings & $\checkmark$ & & \\
\hline & Make training dynamic & $\checkmark$ & & \\
\hline & Audit and provide feedback & $\checkmark$ & $\checkmark$ & \\
\hline & Provide ongoing consultation & $\checkmark$ & $\checkmark$ & \\
\hline & Create a learning collaborative & & $\checkmark$ & \\
\hline \multirow[t]{7}{*}{ ISF Strategy } & External Facilitation & $\checkmark$ & $\checkmark$ & $\checkmark$ \\
\hline & Develop tools for quality improvement & $\checkmark$ & $\checkmark$ & $\checkmark$ \\
\hline & Organize implementation team meetings & $\checkmark$ & $\checkmark$ & $\checkmark$ \\
\hline & Identify and prepare champions & $\checkmark$ & $\checkmark$ & $\checkmark$ \\
\hline & Assess for readiness and identify barriers & $\checkmark$ & $\checkmark$ & $\checkmark$ \\
\hline & Conduct local consensus discussions & & $\checkmark$ & $\checkmark$ \\
\hline & Conduct cyclical small tests of change & & $\checkmark$ & $\checkmark$ \\
\hline
\end{tabular}

Clinical Interventions

UC consisted of referral to formal addiction treatment, mutual-help services, or both. Clients randomized to UC + MIBI received the project's 20-30-minute MIBI for SUD provided by one of the HIV-CBO's prepared/trained MIBI staff. The MIBI was designed to motivate individuals living with HIV who have an SUD to change their substance use by (a) examining their reasons for change, (b) receiving feedback about common negative interactions of substance use and HIV-related health issues, (c) further developing importance or confidence to reduce or stop their primary substance use, and (d) making a plan for change. For more details, see the study protocol paper (67).

\section{Outcome Measures}

Organized by phase (i.e., preparation phase, implementation phase, and sustainment phase), Table 2 details the staff-level outcome measures (i.e., time-to-proficiency, implementation effectiveness, level-of-sustainment) and client-level outcome measures (i.e., days of primary substance use, number of substance-related problems, times engaging in risky behaviors, days of substance use treatment, days of medication non-adherence) collected. 
Table 2

Outcome Measures

\section{Measure Name Measure Description (Phase)}

1. Time-toproficiency (Preparation Phase)
A staff-level measure of the number of weeks between MIBI staff completing the in-person training and demonstrating proficiency in the project's MIBI for SUDs. Developed for this project based on research by Saldana (89). Proficiency was determined by one of the project's MI experts, who rated audio recordings of MIBI practice sessions using the Independent Tape Rater Scale (ITRS) (100). The ITRS is used to rate $10 \mathrm{MI}$-consistent items for adherence and competence along 7-point scales. MIBI proficiency was demonstrated when a single MIBI session had half the items rated at the mid-point or higher for both adherence and competence items.
2. Implementation effectiveness (Implementation Phase)
A staff-level measure of the overall consistency and quality of MIBI implementation during the project's implementation phase. Developed for this project based on research by Klein (21). P PPPFirst, the cumulative number of MIBIs implemented was summed and standardized for each MIBI staff (MIBI consistency). Second, the MIBI proficiency scores were summed and standardized for each MIBI staff (MIBI quality). Proficiency of each MIBI session was assessed by the project's cadre of raters who were trained, calibrated, and supervised by one of the project's MI experts. A quality score was calculated for each MIBI session by multiplying the corresponding adherence rating (ranged from 1-7) and competence rating (ranged from 1-7) and summing for all 10 of the Ml-consistent items (ranged from 10-490). Finally, MIBI consistency and MIBI quality scores were summed and standardized.
3. Intervention effectiveness (Implementation Phase) regarding:

\subsection{Days of} primary substance use substancerelated problems

\subsection{Times} engaging in risky behaviors

\subsection{Days of} substance use treatment

\subsection{Days of HIV} medication nonadherence

\section{Level-of-} sustainment (Sustainment Phase)
A client-level measure of the number of days client participants self-reported using their primary substance during the past 28 days and measured using a modified version of the Addiction Severity Index.(101) Client's primary substance was identified at baseline by asking: "Of the substances that you have used in the past 4 weeks (not including tobacco), which one has been the biggest problem for you OR caused you the most problems?" At follow-up, client participants were reminded of the substance they had indicated was their primary substance.
A client-level measure of the number of the 11 DSM-5(66) substance use disorder symptoms client participants self-reported recognition of regarding their primary substance and during the past 28 days. At follow-up, client participants were reminded of the substance they had indicated was their primary substance.

A client-level measure of the number of times client participants self-reported engaged in unprotected sex, injection drug use, or needle sharing during the past 28 days, which was developed for this project based on the Addiction Severity Index.(101)

A client-level measure of the number of days client participants self-reported having attended residential treatment, outpatient treatment, or self-help group meetings during the past 28 days, which was developed for this project based on the Addiction Severity Index.

A client-level measure of the number of days client participants self-reported having missed at least one dose of their HIV medications during the past 28 days, which was developed for this project based on the on the Addiction Severity Index.(101)

A staff-level measure of the number of MIBIs delivered during the project's 6-month sustainment phase and measured via MIBI staff self-report as part of the project's sustainment phase survey.

Note: $\mathrm{BI}=$ brief intervention; $\mathrm{MIBI}$ = motivational interviewing-based brief intervention. Intervention effectiveness was assessed in terms of the impact of the ISF strategy on each of the client outcome measures.

Moderator Measures

Table 3 details the staff-level measures (i.e., implementation readiness, implementation climate, leadership engagement, tension-for-change, motivational interviewing experience, personal recovery status) hypothesized to moderate the impact of the ISF strategy on the staff-level outcomes. 
Table 3

Staff-level Moderator Measures

\section{Measure Name Measure Description}

Motivational interviewing experience

Personal recovery status

Implementation readiness
A baseline measure of MIBI staff perception of their motivational interviewing experience. Measured by having MIBI staff select one five response options (i.e., none, beginner, intermediate, advanced, or expert).

A baseline measure indicating if MIBI staff considered themselves to be in recovery from alcohol/drugs $(0=$ no; $1=$ yes $)$.

A baseline measure representing MIBI staff perception regarding their organization's readiness for implementing a brief intervention for SUDs. Measured using the average of 12 items developed by Shea (102). Each item (e.g., staff working on this project want to implement this change; staff working on this project are committed to implementing this change; staff working on this project will do whatever it takes to implement this change) was measured on a 5-point scale ( $1=$ Disagree, $2=$ Somewhat Disagree, 3 = Neither Agree nor Disagree, $4=$ Somewhat Agree, $5=$ Agree). Coefficient alpha = .95 .

Implementation climate

A baseline measure representing MIBI staff perception regarding the extent to which implementing brief intervention for SUDs is expected, supported, and rewarded within their organization. Measured using the average of the 6 items developed by Jacobs (103). Each item (e.g., staff working on this project are expected to use brief intervention for substance use with a certain number of clients; staff working on this project get the support they needed to use brief intervention for substance use with eligible clients; staff working on this project receive recognition for using brief intervention for substance use with eligible clients) was measured on a 5-point scale ( 1 = Disagree, 2 = Somewhat Disagree, $3=$ Neither Agree nor Disagree, 4 = Somewhat Agree, $5=$ Agree). Coefficient alpha = .91.

Leadership engagement
Tension-forchange

\begin{abstract}
A baseline measure representing MIBI staff perception regarding the extent to which their HIV-CBOs leadership is committed, involved, engaged, and accountable for implementing brief intervention for SUDs. Measured using 4 items developed for this project based on the leadership engagement construct described by Damschroder (15). Each item (i.e., to what extent was the leadership of this organization committed to the implementation of brief intervention for substance use; to what extent was the leadership of this organization involved in the implementation of brief intervention for substance use; to what extent was the leadership of this organization engaged in the implementation of brief intervention for substance use; to what extent was the leadership of this organization accountable for the implementation of brief intervention for substance use) was measured on 7-point scale $(0=$ not at all to 6 = highest extent possible). Coefficient alpha $=.94$.
\end{abstract}

Note: $\mathrm{MIBI}=$ motivational interviewing-based brief intervention.

The targeted sample size was estimated via power analyses with Optimal Design Software (68). For analyses of staff-level outcomes, it was estimated that $78 \mathrm{MIBI}$ staff nested within $39 \mathrm{HIV}-\mathrm{CBO}$ s would provide $80 \%$ power to detect a statistically significant $(p<.05)$ difference for effect sizes .67 or greater $(14)$. For analyses of client-level outcomes, it was estimated that 1,872 clients, nested within $78 \mathrm{MIBI}$ staff, nested within 39 HIV-CBOs would provide $80 \%$ power to detect a statistically significant difference for effect sizes .20 or greater (24).

\section{Randomization Sequence Generation}

For randomization of HIV-CBOs (i.e., the clusters), each HIV-CBO was allocated to one of two implementation strategy conditions (ATTC; ATTC + ISF) via an urn randomization process (69). Specifically, using survey data collected during the exploration phase from HIV-CBO staff, seven organizational-level factors (i.e., importance of substance use screening, importance of brief intervention for substance use, innovation-value fit, implementation strategy-value fit, implementation climate for $\mathrm{MIBI}$, implementation readiness for $\mathrm{MIBI}$, and implementation effectiveness for $\mathrm{MIBI}$ ) were entered into an urn randomization program (70) that optimized the balance of the two implementation strategy conditions on these factors. 
During the project's implementation phase, HIV-CBOs randomized client participants to one of two intervention conditions (UC; $\mathrm{UC}+\mathrm{MIBI}$ ) via a blocked randomization sequence (blocking size of 6) generated via a blocked randomization program (71). Within each participating HIV-CBO, each MIBI staff had a lock box containing 36 sequentially numbered tamper-evident security envelopes containing a randomization slip indicating condition assignment. The randomization envelope was opened in front of the client participant. Staff updated a centralized recruitment tracking log monitored multiple times per week by research staff.

Blinding

It was not possible to blind HIV-CBOs and their staff to the assigned implementation strategy condition, but the project's ATTC strategy staff and Independent Tape Rater Scale (ITRS) raters were blinded to implementation strategy condition assignment. Additionally, it was not possible to blind HIV-CBOs, their staff, or client participants to clinical intervention condition assignment, but the project's research staff who conducted the follow-up assessments were blinded to all condition assignments.

\section{Statistical Methods}

Statistical analyses were conducted using an intention-to-treat approach. Staff-level outcomes were approximately normal and within-site variation was close to zero. A series of multilevel adjusted analyses was conducted, each of which controlled for project cohort and was weighted via a propensity score weight derived by regressing implementation strategy condition assignment on staff characteristics. The interaction between implementation strategy condition assignment and each hypothesized moderator was examined first, with main effects examined as appropriate.

Client-level outcomes had strong floor effects (e.g., 0 of 28 days) and/or strong ceiling effects (e.g., 28 of 28 days), which led to bimodal u-shaped, j-shaped, or inverted j-shaped distributions. Given these non-normal distributions, linear regression analyses were not appropriate. Rather, these types of distributions are appropriately addressed using zero-and-one inflated beta (ZOIB) regression after data are transformed to a proportion scale (i.e., 0 to 1 ). The ZOIB model is a mixture model with three parts: (a) a prediction of the probability of the ceiling effect vs. other values (i.e., the ceiling effect), (b) a prediction of the mean for values in between, but not including, the floor and ceiling effect (i.e., non-ceiling/non-floor effect), and (c) a prediction of the probability of the floor effect vs. other values (i.e., the floor effect). We fit three-level multilevel ZOIB models to account for nesting of client participants within MIBI staff and MIBI staff within HIV-CBOs using the R package developed by Liu (72). Each ZOIB model was adjusted for the baseline value of the respective outcome measure, client characteristics (i.e., age, White, male, heterosexual, transgender, married, high school or higher, alcohol as primary substance, engagement in HIV care), project cohort, randomization to ATTC + ISF condition, randomization to UC + MIBI condition, and the cross-level interaction between ATTC + ISF condition and UC + MIBI condition .

\section{Results}

Participant Flow and Recruitment

For study feasibility, HIV-CBOs were recruited in three cohorts, each lasting 20 months from the randomization of HIV-CBOs to the final data collection. The first cohort, in the central United States, occurred January 2015 through August 2016, and resulted in the recruitment of $14 \mathrm{HIV}-\mathrm{CBO}$, $28 \mathrm{MIBI}$ staff, and 191 client participants. The second cohort, in the western United States, occurred January 2016 through August 2017, and resulted in the recruitment of 11 HIV-CBOs, 22 MIBI staff, and 300 client participants. The third cohort, in the eastern United States, occurred January 2017 through August 2018, and resulted in the recruitment of $14 \mathrm{HIV}-\mathrm{CBOs}, 28 \mathrm{MIBI}$ staff, and 333 clients. Figure 2 details the flow of HIV-CBOs, MIBI staff, and client participants through the project's preparation, implementation, and sustainment phases.

Baseline Characteristics

Page 10/31 
Table 4 presents baseline characteristics for MIBI staff participants for the overall sample $(\mathrm{N}=78)$ and each condition (ATTC = 38; ATTC + ISF $=40)$. Overall, MIBI staff participants were/had: $25-34$ years of age $(46 \%)$, female $(71 \%)$, Caucasian/White (62\%), a graduate degree or higher (50\%), 12 months or less tenure with current HIV-CBO (35\%), and intermediate motivational interviewing experience or higher (53\%). 
Table 4

Staff Characteristics at Baseline

\begin{tabular}{|c|c|c|c|c|c|c|}
\hline & \multicolumn{2}{|c|}{$\begin{array}{l}\text { Overall } \\
(n=78)\end{array}$} & \multicolumn{2}{|c|}{$\begin{array}{l}\text { ATTC } \\
(n=38)\end{array}$} & \multicolumn{2}{|c|}{$\begin{array}{l}\text { ATTC + ISF } \\
(n=40)\end{array}$} \\
\hline & $\mathrm{n}$ & $\%$ & $\mathrm{n}$ & $\%$ & $\mathrm{n}$ & $\%$ \\
\hline \multicolumn{7}{|l|}{ Age } \\
\hline $18-24$ & 3 & 3.8 & 2 & 5.3 & 1 & 2.5 \\
\hline $25-34$ & 36 & 46.2 & 12 & 31.6 & 24 & 60.0 \\
\hline $35-44$ & 16 & 20.5 & 9 & 23.7 & 7 & 17.5 \\
\hline $45-54$ & 14 & 17.9 & 9 & 23.7 & 5 & 12.5 \\
\hline $55-64$ & 9 & 11.5 & 6 & 15.8 & 3 & 7.5 \\
\hline \multicolumn{7}{|l|}{ Biological Sex } \\
\hline Female & 55 & 70.5 & 26 & 68.4 & 29 & 72.5 \\
\hline Male & 23 & 29.5 & 12 & 31.6 & 11 & 27.5 \\
\hline Hispanic or Latino & 16 & 20.5 & 11 & 28.9 & 5 & 12.5 \\
\hline \multicolumn{7}{|l|}{ Race } \\
\hline African American/Black & 27 & 34.6 & 14 & 36.8 & 13 & 32.5 \\
\hline Asian & 3 & 3.8 & 1 & 2.6 & 2 & 5.0 \\
\hline Caucasian/White & 48 & 61.5 & 23 & 60.5 & 25 & 62.5 \\
\hline Graduate degree or higher & 39 & 50.0 & 16 & 42.1 & 23 & 57.5 \\
\hline \multicolumn{7}{|l|}{ Experience in current profession } \\
\hline 12 months or less & 14 & 17.9 & 6 & 15.8 & 8 & 20.0 \\
\hline $13-24$ months & 10 & 12.8 & 2 & 5.3 & 8 & 20.0 \\
\hline $25-60$ months & 15 & 19.2 & 7 & 18.4 & 8 & 20.0 \\
\hline $81-120$ months & 18 & 23.1 & 10 & 26.3 & 8 & 20.0 \\
\hline $121+$ months & 21 & 26.9 & 13 & 34.2 & 8 & 20.0 \\
\hline \multicolumn{7}{|l|}{ Tenure at current organization } \\
\hline 12 months or less & 27 & 34.6 & 17 & 44.7 & 10 & 25.0 \\
\hline $13-24$ months & 20 & 25.6 & 6 & 15.8 & 14 & 35.0 \\
\hline $25-60$ months & 15 & 19.2 & 6 & 15.8 & 9 & 22.5 \\
\hline $81-120$ months & 9 & 11.5 & 4 & 10.5 & 5 & 12.5 \\
\hline $121+$ months & 7 & 9.0 & 5 & 13.2 & 2 & 5.0 \\
\hline \multicolumn{7}{|l|}{ Moderator measures } \\
\hline Intermediate MI experience or higher & 41 & 52.6 & 22 & 57.9 & 19 & 47.5 \\
\hline
\end{tabular}




\begin{tabular}{|c|c|c|c|c|c|c|}
\hline & \multicolumn{2}{|c|}{$\begin{array}{l}\text { Overall } \\
(n=78)\end{array}$} & \multicolumn{2}{|c|}{$\begin{array}{l}\text { ATTC } \\
(n=38)\end{array}$} & \multicolumn{2}{|c|}{$\begin{array}{l}\text { ATTC + ISF } \\
(n=40)\end{array}$} \\
\hline & $\mathbf{n}$ & $\%$ & $\mathbf{n}$ & $\%$ & $\mathbf{n}$ & $\%$ \\
\hline In recovery for alcohol or drugs & 11 & 14.1 & 8 & 21.1 & 3 & 7.5 \\
\hline Readiness for implementing change [mean (SD)] & 78 & $2.9(1.4)$ & 38 & $3.3(1.4)$ & 40 & $2.6(1.4)$ \\
\hline Implementation climate [mean (SD)] & 78 & $2.8(1.1)$ & 38 & $3.0(1.1)$ & 40 & $2.7(1.1)$ \\
\hline Leadership engagement [mean (SD)] & 78 & $3.7(1.7)$ & 38 & $3.8(1.6)$ & 40 & $3.5(1.7)$ \\
\hline Tension-for-change [mean (SD)] & 78 & $4.4(1.4)$ & 38 & $4.5(1.3)$ & 40 & $4.4(1.4)$ \\
\hline
\end{tabular}

Table 5 presents baseline characteristics for client participants for the overall sample $(\mathrm{N}=824)$ and each condition (ATTC \& $U C=134 ; A T T C \& U C+M I B I=130 ; A T T C+I S F \& U C=281 ; A T T C+I S F \& U C+M I B I=279)$. Overall, clients were/had: male (76\%), African American/Black (54\%), heterosexual (42\%), a high school graduate or higher (70\%), and engaged in HIV care (95\%). Primary substance use for the overall sample was: alcohol (37\%), cannabis (23\%), cocaine/crack (18\%), methamphetamine (17\%), heroin (2\%), and other (3\%). On average, client participants reported using their primary substance 16 days during the past 28 days ( $57 \%$ of days). However, $222(27 \%)$ of client participants reported using their primary substance daily during the past 28 days (i.e., ceiling effect; see Fig. 3 ). 
Table 5

Client Characteristics at Baseline

\begin{tabular}{|c|c|c|c|c|c|c|c|c|c|c|}
\hline & \multicolumn{2}{|c|}{$\begin{array}{l}\text { Overall } \\
(n=824)\end{array}$} & \multicolumn{2}{|c|}{$\begin{array}{l}\text { ATTC } \\
\& \text { UC } \\
(n=134)\end{array}$} & \multicolumn{2}{|c|}{$\begin{array}{l}\text { ATTC } \\
\& \text { UC + MIBI } \\
(n=130)\end{array}$} & \multicolumn{2}{|c|}{$\begin{array}{l}\text { ATTC+ ISF } \\
\& \text { UC } \\
(n=281)\end{array}$} & \multicolumn{2}{|c|}{$\begin{array}{l}\text { ATTC + ISF } \\
\& \text { UC + MIBI } \\
(n=279)\end{array}$} \\
\hline & $n$ & $\%$ & n & $\%$ & $\mathbf{n}$ & $\%$ & $\mathrm{n}$ & $\%$ & $\mathrm{n}$ & $\%$ \\
\hline \multicolumn{11}{|l|}{ Age } \\
\hline $18-24$ & 46 & 5.6 & 5 & 3.8 & 3 & 2.3 & 16 & 5.7 & 22 & 7.9 \\
\hline $25-34$ & 138 & 16.8 & 27 & 20.3 & 25 & 19.2 & 46 & 16.4 & 40 & 14.3 \\
\hline $35-44$ & 179 & 21.7 & 24 & 18.0 & 24 & 18.5 & 69 & 24.6 & 62 & 22.2 \\
\hline $45-54$ & 287 & 34.9 & 51 & 38.3 & 43 & 33.1 & 99 & 35.2 & 94 & 33.7 \\
\hline $55-64$ & 156 & 19.0 & 24 & 18.0 & 31 & 23.8 & 49 & 17.4 & 52 & 18.6 \\
\hline $65+$ & 17 & 2.1 & 2 & 1.5 & 4 & 3.1 & 2 & 0.7 & 9 & 3.2 \\
\hline \multicolumn{11}{|l|}{ Biological Sex } \\
\hline Male & 627 & 76.1 & 99 & 73.9 & 91 & 70.0 & 220 & 78.3 & 217 & 77.8 \\
\hline Female & 197 & 23.9 & 35 & 26.1 & 39 & 30.0 & 61 & 21.7 & 62 & 22.2 \\
\hline \multicolumn{11}{|l|}{ Gender Identity } \\
\hline Male & 575 & 69.9 & 91 & 67.9 & 87 & 66.9 & 203 & 72.5 & 194 & 69.5 \\
\hline Female & 203 & 24.7 & 35 & 26.1 & 38 & 29.2 & 65 & 23.2 & 65 & 23.3 \\
\hline Transgender & 45 & 5.5 & 8 & 6.0 & 5 & 3.8 & 12 & 4.3 & 20 & 7.2 \\
\hline Hispanic or Latino & 109 & 13.2 & 22 & 16.4 & 17 & 13.1 & 37 & 13.2 & 33 & 11.8 \\
\hline \multicolumn{11}{|l|}{ Race } \\
\hline African American/Black & 447 & 54.2 & 77 & 57.5 & 72 & 55.4 & 161 & 57.3 & 137 & 49.1 \\
\hline American Indian/Alaska Native & 23 & 2.8 & 1 & 0.75 & 2 & 1.5 & 6 & 2.1 & 14 & 5.0 \\
\hline Asian & 4 & 0.5 & 0 & 0.0 & 0 & 0 & 3 & 1.1 & 1 & 0.4 \\
\hline Caucasian/White & 298 & 36.2 & 48 & 35.8 & 50 & 38.5 & 96 & 34.5 & 104 & 37.6 \\
\hline $\begin{array}{l}\text { Native Hawaiian/Other Pacific } \\
\text { Islander }\end{array}$ & 10 & 1.2 & 0 & 0.0 & 1 & 0.8 & 2 & 0.7 & 7 & 2.5 \\
\hline More than one & 20 & 2.4 & 2 & 1.5 & 2 & 1.5 & 7 & 2.5 & 9 & 3.2 \\
\hline \multicolumn{11}{|l|}{ Sexual Orientation } \\
\hline Heterosexual & 347 & 42.1 & 60 & 44.8 & 70 & 53.8 & 97 & 34.6 & 120 & 43.2 \\
\hline Homosexual, gay, or lesbian & 315 & 38.3 & 51 & 38.1 & 40 & 30.8 & 124 & 44.3 & 100 & 36.0 \\
\hline Other & 160 & 19.5 & 23 & 17.2 & 20 & 15.4 & 59 & 21.0 & 58 & 20.8 \\
\hline Married & 109 & 13.2 & 16 & 11.9 & 26 & 20.0 & 36 & 12.8 & 31 & 11.1 \\
\hline
\end{tabular}

Note: ATTC = Addiction Technology Transfer Center; ISF = Implementation \& Sustainment Facilitation; $\mathrm{MIBI}=$ motivational interviewing-based brief intervention; UC = usual care 


\begin{tabular}{|c|c|c|c|c|c|c|c|c|c|c|}
\hline & \multicolumn{2}{|c|}{$\begin{array}{l}\text { Overall } \\
(n=824)\end{array}$} & \multicolumn{2}{|c|}{$\begin{array}{l}\text { ATTC } \\
\& \text { UC } \\
(n=134)\end{array}$} & \multicolumn{2}{|c|}{$\begin{array}{l}\text { ATTC } \\
\& \text { UC + MIBI } \\
(n=130)\end{array}$} & \multicolumn{2}{|c|}{$\begin{array}{l}\text { ATTC + ISF } \\
\& \text { UC } \\
(n=281)\end{array}$} & \multicolumn{2}{|c|}{$\begin{array}{l}\text { ATTC + ISF } \\
\& \text { UC + MIBI } \\
(n=279)\end{array}$} \\
\hline & $\mathbf{n}$ & $\%$ & $\mathbf{n}$ & $\%$ & $\mathbf{n}$ & $\%$ & $\mathbf{n}$ & $\%$ & $\mathbf{n}$ & $\%$ \\
\hline Highschool graduate or higher & 576 & 70.4 & 94 & 71.8 & 86 & 66.7 & 203 & 72.2 & 193 & 69.7 \\
\hline Engaged in HIV care & 778 & 95.2 & 127 & 95.5 & 122 & 94.6 & 260 & 93.5 & 269 & 97.1 \\
\hline \multicolumn{11}{|l|}{ Primary Substance } \\
\hline Alcohol & 304 & 36.9 & 56 & 41.8 & 54 & 41.5 & 99 & 35.2 & 95 & 34.0 \\
\hline Cannabis & 186 & 22.6 & 35 & 26.1 & 37 & 28.5 & 57 & 20.3 & 57 & 20.4 \\
\hline Cocaine/Crack & 145 & 17.6 & 23 & 17.2 & 15 & 11.5 & 52 & 18.5 & 55 & 19.7 \\
\hline Methamphetamine & 143 & 17.4 & 12 & 9.0 & 14 & 10.8 & 59 & 21.0 & 58 & 20.8 \\
\hline Heroin & 20 & 2.4 & 2 & 1.5 & 6 & 4.6 & 7 & 2.5 & 5 & 1.8 \\
\hline Other & 26 & 3.2 & 6 & 4.5 & 4 & 3.1 & 7 & 2.5 & 9 & 3.2 \\
\hline Outcome measures & $n$ & $\begin{array}{l}\text { mean } \\
(\mathrm{SD})\end{array}$ & $\mathrm{n}$ & $\begin{array}{l}\text { mean } \\
(S D)\end{array}$ & $\mathrm{n}$ & $\begin{array}{l}\text { mean } \\
\text { (SD) }\end{array}$ & $\mathrm{n}$ & $\begin{array}{l}\text { mean } \\
(S D)\end{array}$ & $\mathrm{n}$ & $\begin{array}{l}\text { mean } \\
\text { (SD) }\end{array}$ \\
\hline Days of use & 823 & $\begin{array}{l}15.9 \\
(9.7)\end{array}$ & 134 & $\begin{array}{l}16.3 \\
(9.8)\end{array}$ & 130 & $\begin{array}{l}16.9 \\
(9.9)\end{array}$ & 280 & $\begin{array}{l}15.6 \\
(9.7)\end{array}$ & 279 & $\begin{array}{l}15.4 \\
(9.5)\end{array}$ \\
\hline Problem recognition & 824 & $\begin{array}{l}7.3 \\
(3.1)\end{array}$ & 134 & $\begin{array}{l}6.9 \\
(3.1)\end{array}$ & 130 & $\begin{array}{l}7.0 \\
(3.2)\end{array}$ & 281 & $\begin{array}{l}7.4 \\
(3.2)\end{array}$ & 279 & $\begin{array}{l}7.4 \\
(3.1)\end{array}$ \\
\hline Risky behaviors & 818 & $\begin{array}{l}3.8 \\
(9.8)\end{array}$ & 132 & $\begin{array}{l}2.8 \\
(10.7)\end{array}$ & 130 & $\begin{array}{l}3.4 \\
(7.5)\end{array}$ & 279 & $\begin{array}{l}4.2 \\
(11.2)\end{array}$ & 277 & $\begin{array}{l}4.1 \\
(8.7)\end{array}$ \\
\hline Engagement in SUD treatment & 822 & $\begin{array}{l}2.4 \\
(7.1)\end{array}$ & 133 & $\begin{array}{l}3.2 \\
(8.5)\end{array}$ & 129 & $\begin{array}{l}2.0 \\
(6.5)\end{array}$ & 281 & $\begin{array}{l}2.1 \\
(7.5)\end{array}$ & 279 & $\begin{array}{l}2.5 \\
(6.2)\end{array}$ \\
\hline Days of missed HIV medication & 740 & $\begin{array}{l}3.8 \\
(6.3)\end{array}$ & 126 & $\begin{array}{l}3.6 \\
(6.2)\end{array}$ & 120 & $\begin{array}{l}3.5 \\
(5.8)\end{array}$ & 240 & $\begin{array}{l}4.1 \\
(6.4)\end{array}$ & 254 & $\begin{array}{l}3.8 \\
(6.4)\end{array}$ \\
\hline
\end{tabular}

Outcomes

Table 6 summarizes results of analyses focused on testing the extent to which the ISF strategy (ATTC + ISF strategy compared to ATTC strategy) had an impact on the staff-level outcomes. Consistent with our hypotheses, results of each moderator analysis are presented first, with a main effect analysis reported as appropriate. 
Table 6

Moderator-first analyses of the impact of the ISF strategy on time-to-proficiency, implementation effectiveness, and level-ofsustainment

\begin{tabular}{|c|c|c|c|c|c|c|c|c|c|}
\hline & \multicolumn{3}{|c|}{$\begin{array}{l}\text { Time-to-Proficiency } \\
(\mathrm{ICC}=.22)\end{array}$} & \multicolumn{3}{|c|}{$\begin{array}{l}\text { Implementation } \\
\text { Effectiveness } \\
(\text { ICC }=.06)\end{array}$} & \multicolumn{3}{|c|}{$\begin{array}{l}\text { Level of Sustainment } \\
(\text { ICC }=.001)\end{array}$} \\
\hline & $\begin{array}{l}\text { Estimate } \\
(95 \% \mathrm{Cl})\end{array}$ & SE & $\begin{array}{l}p \\
\text { value }\end{array}$ & $\begin{array}{l}\text { Estimate } \\
(95 \% \mathrm{Cl})\end{array}$ & SE & $\begin{array}{l}\mathrm{P} \\
\text { value }\end{array}$ & $\begin{array}{l}\text { Estimate } \\
(95 \% \mathrm{Cl})\end{array}$ & SE & $\begin{array}{l}\mathrm{p} \\
\text { value }\end{array}$ \\
\hline \multicolumn{10}{|l|}{ MI Experience } \\
\hline ATTC + ISF & $\begin{array}{l}-0.35 \\
(-0.93,0.23)\end{array}$ & 0.30 & 0.24 & $\begin{array}{l}0.70 \\
(0.10,1.30)\end{array}$ & 0.30 & 0.03 & $\begin{array}{l}0.34 \\
(-0.42,1.10)\end{array}$ & 0.39 & 0.39 \\
\hline $\begin{array}{l}\text { MI experience } \\
\text { (intermediate plus) }\end{array}$ & $\begin{array}{l}-0.02 \\
(-0.58,0.54)\end{array}$ & 0.29 & 0.95 & $\begin{array}{l}0.20 \\
(-0.38,0.78)\end{array}$ & 0.30 & 0.50 & $\begin{array}{l}0.18 \\
(-0.56,0.92)\end{array}$ & 0.38 & 0.64 \\
\hline ATTC + ISF x MI experience & $\begin{array}{l}0.63 \\
(-0.14,1.40)\end{array}$ & 0.39 & 0.11 & $\begin{array}{l}-0.07 \\
(-0.87,0.73)\end{array}$ & 0.41 & 0.86 & $\begin{array}{l}-0.47 \\
(-1.49,0.55)\end{array}$ & 0.52 & 0.37 \\
\hline \multicolumn{10}{|l|}{ Personal Recovery Status } \\
\hline ATTC + ISF & $\begin{array}{l}0.09 \\
(-0.33,0.51)\end{array}$ & 0.21 & 0.67 & $\begin{array}{l}0.70 \\
(0.27,1.13)\end{array}$ & 0.22 & 0.01 & $\begin{array}{l}0.26 \\
(-0.28,0.80)\end{array}$ & 0.28 & 0.34 \\
\hline In recovery & $\begin{array}{l}0.35 \\
(-0.39,1.09)\end{array}$ & 0.38 & 0.35 & $\begin{array}{l}-0.01 \\
(-0.77,0.75)\end{array}$ & 0.39 & 0.98 & $\begin{array}{l}0.64 \\
(-0.33,1.61)\end{array}$ & 0.49 & 0.20 \\
\hline ATTC + ISF x In recovery & $\begin{array}{l}-0.90 \\
(-2.04,0.24)\end{array}$ & 0.58 & 0.13 & $\begin{array}{l}-0.58 \\
(-1.75,0.59)\end{array}$ & 0.60 & 0.33 & $\begin{array}{l}-1.36 \\
(-2.84,0.12)\end{array}$ & 0.76 & 0.08 \\
\hline \multicolumn{10}{|l|}{ Implementation Readiness } \\
\hline ATTC + ISF & $\begin{array}{l}0.43 \\
(-0.53,1.39)\end{array}$ & 0.49 & 0.38 & $\begin{array}{l}-0.06 \\
(-1.03,0.91)\end{array}$ & 0.50 & 0.90 & $\begin{array}{l}-0.40 \\
(-1.67,0.87)\end{array}$ & 0.65 & 0.54 \\
\hline Implementation Readiness & $\begin{array}{l}0.15 \\
(-0.06,0.36)\end{array}$ & 0.11 & 0.16 & $\begin{array}{l}-0.20 \\
(-0.41,0.01)\end{array}$ & 0.11 & 0.06 & $\begin{array}{l}-0.08 \\
(-0.35,0.19)\end{array}$ & 0.14 & 0.58 \\
\hline $\begin{array}{l}\text { ATTC + ISF x } \\
\text { Implementation Readiness }\end{array}$ & $\begin{array}{l}-0.13 \\
(-0.41,0.15)\end{array}$ & 0.15 & 0.36 & $\begin{array}{l}0.21 \\
(-0.08,0.50)\end{array}$ & 0.15 & 0.16 & $\begin{array}{l}0.16 \\
(-0.22,0.54)\end{array}$ & 0.19 & 0.41 \\
\hline \multicolumn{10}{|l|}{ Implementation Climate } \\
\hline ATTC + ISF & $\begin{array}{l}0.20 \\
(-0.93,1.33)\end{array}$ & 0.58 & 0.73 & $\begin{array}{l}0.68 \\
(-0.48,1.84)\end{array}$ & 0.59 & 0.26 & $\begin{array}{l}-0.56 \\
(-2.04,0.92)\end{array}$ & 0.75 & 0.46 \\
\hline Implementation Climate & $\begin{array}{l}0.02 \\
(-0.25,0.29)\end{array}$ & 0.14 & 0.86 & $\begin{array}{l}-0.05 \\
(-0.33,0.23)\end{array}$ & 0.14 & 0.71 & $\begin{array}{l}-0.15 \\
(-0.50,0.20)\end{array}$ & 0.18 & 0.41 \\
\hline $\begin{array}{l}\text { ATTC + ISF x } \\
\text { Implementation Climate }\end{array}$ & $\begin{array}{l}-0.08 \\
(-0.43,0.27)\end{array}$ & 0.18 & 0.67 & $\begin{array}{l}-0.02 \\
(-0.38,0.34)\end{array}$ & 0.19 & 0.93 & $\begin{array}{l}0.21 \\
(-0.25,0.67)\end{array}$ & 0.24 & 0.37 \\
\hline \multicolumn{10}{|l|}{ Leadership Engagement } \\
\hline ATTC + ISF & $\begin{array}{l}0.18 \\
(-0.82,1.18)\end{array}$ & 0.51 & 0.72 & $\begin{array}{l}0.04 \\
(-0.98,1.06)\end{array}$ & 0.52 & 0.94 & $\begin{array}{l}-0.53 \\
(-1.84,0.78)\end{array}$ & 0.67 & 0.43 \\
\hline Leadership Engagement & $\begin{array}{l}0.02 \\
(-0.16,0.20)\end{array}$ & 0.09 & 0.84 & $\begin{array}{l}-0.12 \\
(-0.3,0.06)\end{array}$ & 0.09 & 0.21 & $\begin{array}{l}-0.03 \\
(-0.26,0.20)\end{array}$ & 0.12 & 0.82 \\
\hline
\end{tabular}

Note: ICC = intracluster correlation; ATTC = Addiction Technology Transfer Center; $\mathrm{Cl}=$ confidence interval; ISF = Implementation \& Sustainment Facilitation; $\mathrm{MI}=$ motivational interviewing. 


\begin{tabular}{|c|c|c|c|c|c|c|c|c|c|}
\hline & \multicolumn{3}{|c|}{$\begin{array}{l}\text { Time-to-Proficiency } \\
(\mathrm{ICC}=.22)\end{array}$} & \multicolumn{3}{|c|}{$\begin{array}{l}\text { Implementation } \\
\text { Effectiveness } \\
(I C C=.06)\end{array}$} & \multicolumn{3}{|c|}{$\begin{array}{l}\text { Level of Sustainment } \\
(\text { ICC }=.001)\end{array}$} \\
\hline & $\begin{array}{l}\text { Estimate } \\
(95 \% \mathrm{Cl})\end{array}$ & SE & $\begin{array}{l}p \\
\text { value }\end{array}$ & $\begin{array}{l}\text { Estimate } \\
(95 \% \mathrm{Cl})\end{array}$ & SE & $\begin{array}{l}p \\
\text { value }\end{array}$ & $\begin{array}{l}\text { Estimate } \\
(95 \% \mathrm{Cl})\end{array}$ & SE & $\begin{array}{l}\mathrm{p} \\
\text { value }\end{array}$ \\
\hline $\begin{array}{l}\text { ATTC + ISF x Leadership } \\
\text { Engagement }\end{array}$ & $\begin{array}{l}-0.06 \\
(-0.31,0.19)\end{array}$ & 0.13 & 0.66 & $\begin{array}{l}0.16 \\
(-0.09,0.41)\end{array}$ & 0.13 & 0.22 & $\begin{array}{l}0.17 \\
(-0.15,0.49)\end{array}$ & 0.16 & 0.31 \\
\hline \multicolumn{10}{|l|}{ Tension-for-Change } \\
\hline ATTC + ISF & $\begin{array}{l}0.20 \\
(-1.25,1.65)\end{array}$ & 0.74 & 0.79 & $\begin{array}{l}0.08 \\
(-1.40,1.56)\end{array}$ & 0.76 & 0.91 & $\begin{array}{l}-0.30 \\
(-2.21,1.61)\end{array}$ & 0.97 & 0.76 \\
\hline Tension-for-Change & $\begin{array}{l}-0.01 \\
(-0.24,0.22)\end{array}$ & 0.12 & 0.93 & $\begin{array}{l}-0.01 \\
(-0.25,0.23)\end{array}$ & 0.12 & 0.91 & $\begin{array}{l}-0.10 \\
(-0.40,0.20)\end{array}$ & 0.16 & 0.54 \\
\hline $\begin{array}{l}\text { ATTC + ISF x Tension-for- } \\
\text { Change }\end{array}$ & $\begin{array}{l}-0.05 \\
(-0.36,0.26)\end{array}$ & 0.16 & 0.76 & $\begin{array}{l}0.12 \\
(-0.19,0.43)\end{array}$ & 0.16 & 0.44 & $\begin{array}{l}0.08 \\
(-0.32,0.48)\end{array}$ & 0.21 & 0.69 \\
\hline \multicolumn{10}{|l|}{ Main Effect } \\
\hline ATTC + ISF & $\begin{array}{l}-0.02 \\
(-0.41,0.37)\end{array}$ & 0.20 & 0.91 & $\begin{array}{l}0.65 \\
(0.25,1.05)\end{array}$ & 0.20 & 0.00 & $\begin{array}{l}0.09 \\
(-0.42,0.60)\end{array}$ & 0.26 & 0.74 \\
\hline
\end{tabular}

For time-to-proficiency, none of the hypothesized moderators were found to be significant. Further, the ISF strategy was not found to have a significant main effect on decreasing time-to-proficiency $(\beta=-0.02 ; 95 \%$ confidence interval $[\mathrm{Cl}]=-0.41,0.37)$. On average, time-to-proficiency was 12.35 weeks $(S D=3.18)$ for MIBI staff in the ATTC condition and 11.44 days $(S D=4.87)$ for MIBI staff in the ATTC + ISF condition.

For implementation effectiveness, none of the hypothesized moderators were found to be significant. However, the ISF strategy was found to have a significant main effect on increasing implementation effectiveness $(\beta=0.65 ; 95 \% \mathrm{Cl}=0.25,1.05, \mathrm{p}<.01)$. On average, the sum number of MIBIs implemented during the implementation phase (the consistency dimension of staff-level implementation effectiveness) was 3.34 (SD = 4.19) for MIBI staff in the ATTC condition and $6.92(\mathrm{SD}=5.49)$ for MIBI staff in the ATTC + ISF condition. On average, the sum quality score of MIBIs (the quality dimension of staff-level implementation effectiveness, was 558 (SD = 777) for MIBI staff in the ATTC condition and 1310 (SD = 1053) for MIBI staff in the ATTC + ISF condition.

For level-of-sustainment, none of the six hypothesized moderators were found to be significant and there was not a significant main effect for the ISF strategy $(\beta=0.09 ; 95 \% \mathrm{Cl}=0.42,0.60)$. On average, the number of MIBIs implemented during the sustainment phase was $3.42(S D=6.31)$ for MIBI staff in the ATTC condition and $3.18(S D=8.33)$ for MIBI staff in the ATTC + ISF condition.

Table 7 summarizes results of analyses focused on testing the extent to which the ISF strategy (ATTC + ISF strategy compared to ATTC strategy) had an impact on the effectiveness of the MIBI to improve client outcomes (i.e., intervention effectiveness). Consistent with our hypotheses, the cross-level interactions between implementation condition and clinical intervention condition (i.e., ATTC + ISF x UC + MIBI) are presented first, with the other key terms (i.e., ATTC + ISF, UC + MIBI) presented below. 
Table 7

Cross-level Interactions Examining the Impact of the ISF Strategy on the Intervention Effectiveness of the MIBI

\begin{tabular}{|c|c|c|c|c|c|c|c|c|c|c|}
\hline & \multicolumn{2}{|c|}{$\begin{array}{l}\text { Days of Primary } \\
\text { Substance Use } \\
(\text { ICC = .07) }\end{array}$} & \multicolumn{2}{|c|}{$\begin{array}{l}\text { Number of } \\
\text { Substance-Related } \\
\text { Problems } \\
(\text { ICC = .06) }\end{array}$} & \multicolumn{2}{|c|}{$\begin{array}{l}\text { Times Engaging in } \\
\text { Risky Behaviors } \\
(\mathrm{ICC}=.03)\end{array}$} & \multicolumn{2}{|c|}{$\begin{array}{l}\text { Days of Substance } \\
\text { Use Treatment } \\
(\text { ICC }=.03)\end{array}$} & \multicolumn{2}{|c|}{$\begin{array}{l}\text { Days of HIV } \\
\text { Medication Non- } \\
\text { Adherence } \\
(\text { ICC = .01) }\end{array}$} \\
\hline & $\begin{array}{l}\text { OR } \\
(95 \% \mathrm{Cl})\end{array}$ & $\begin{array}{l}\mathrm{P} \\
\text { value }\end{array}$ & $\begin{array}{l}\text { OR } \\
(95 \% \mathrm{Cl})\end{array}$ & $\begin{array}{l}\mathrm{p} \\
\text { value }\end{array}$ & $\begin{array}{l}\text { OR } \\
(95 \% \mathrm{Cl})\end{array}$ & $\begin{array}{l}p \\
\text { value }\end{array}$ & $\begin{array}{l}\text { OR } \\
(95 \% \mathrm{Cl})\end{array}$ & $\begin{array}{l}\mathrm{P} \\
\text { value }\end{array}$ & $\begin{array}{l}\text { OR } \\
(95 \% \mathrm{Cl})\end{array}$ & $\begin{array}{l}\mathrm{p} \\
\text { value }\end{array}$ \\
\hline \multicolumn{11}{|l|}{$\begin{array}{l}\text { Ceiling } \\
\text { Effect }\end{array}$} \\
\hline $\begin{array}{l}\text { UC+ } \\
\text { MIBI x } \\
\text { ATTC+ } \\
\text { ISF }\end{array}$ & $\begin{array}{l}0.11 \\
(0.08,0.15)\end{array}$ & 0.02 & $\begin{array}{l}0.26 \\
(0.20,0.36)\end{array}$ & 0.16 & & & & & • & \\
\hline $\begin{array}{l}\text { ATTC + } \\
\text { ISF }\end{array}$ & $\begin{array}{l}4.11 \\
(3.25,5.19)\end{array}$ & 0.04 & $\begin{array}{l}6.68 \\
(5.39,8.28)\end{array}$ & 0.01 & & & & & $\begin{array}{l}2.50 \\
(2.07,3.02)\end{array}$ & 0.50 \\
\hline $\begin{array}{l}\mathrm{UC}+ \\
\mathrm{MIBI}\end{array}$ & $\begin{array}{l}1.87 \\
(1.44,2.42)\end{array}$ & 0.39 & $\begin{array}{l}1.50 \\
(1.18,1.91)\end{array}$ & 0.62 & & & & & $\begin{array}{l}0.36 \\
(0.29,0.45)\end{array}$ & 0.13 \\
\hline \multicolumn{11}{|l|}{$\begin{array}{l}\text { Non- } \\
\text { Ceiling/ } \\
\text { Non- } \\
\text { Floor } \\
\text { Effect }\end{array}$} \\
\hline $\begin{array}{l}\text { UC+ }+ \\
\text { MIBI x } \\
\text { ATTC+ } \\
\text { ISF }\end{array}$ & $\begin{array}{l}1.03 \\
(0.74,1.43)\end{array}$ & 0.87 & $\begin{array}{l}0.86 \\
(0.64,1.16)\end{array}$ & 0.33 & $\begin{array}{l}0.62 \\
(0.36,1.08)\end{array}$ & 0.10 & $\begin{array}{l}1.39 \\
(0.79,2.44)\end{array}$ & 0.25 & $\begin{array}{l}1.18 \\
(0.90,1.55)\end{array}$ & 0.23 \\
\hline $\begin{array}{l}\text { ATTC + } \\
\text { ISF }\end{array}$ & $\begin{array}{l}1.02 \\
(0.81,1.29)\end{array}$ & 0.86 & $\begin{array}{l}1.36 \\
(1.09,1.68)\end{array}$ & 0.01 & $\begin{array}{l}1.02 \\
(0.66,1.56)\end{array}$ & 0.93 & $\begin{array}{l}0.95 \\
(0.65,1.40)\end{array}$ & 0.81 & $\begin{array}{l}1.09 \\
(0.90,1.32)\end{array}$ & 0.36 \\
\hline $\begin{array}{l}\mathrm{UC}+ \\
\mathrm{MIBI}\end{array}$ & $\begin{array}{l}1.09 \\
(0.84,1.41)\end{array}$ & 0.53 & $\begin{array}{l}1.05 \\
(0.82,1.33)\end{array}$ & 0.72 & $\begin{array}{l}1.26 \\
(0.78,2.05)\end{array}$ & 0.35 & $\begin{array}{l}0.72 \\
(0.45,1.15)\end{array}$ & 0.17 & $\begin{array}{l}0.88 \\
(0.70,1.10)\end{array}$ & 0.25 \\
\hline \multicolumn{11}{|l|}{$\begin{array}{l}\text { Floor } \\
\text { Effect }\end{array}$} \\
\hline $\begin{array}{l}\text { UC+ } \\
\text { MIBI x } \\
\text { ATTC+ } \\
\text { ISF }\end{array}$ & $\begin{array}{l}1.51 \\
(1.09,2.10)\end{array}$ & 0.58 & $\begin{array}{l}1.51 \\
(1.12,2.03)\end{array}$ & 0.73 & $\begin{array}{l}0.91 \\
(0.52,1.59)\end{array}$ & 0.86 & $\begin{array}{l}0.82 \\
(0.47,1.44)\end{array}$ & 0.62 & $\begin{array}{l}0.89 \\
(0.68,1.17)\end{array}$ & 0.75 \\
\hline $\begin{array}{l}\text { ATTC + } \\
\text { ISF }\end{array}$ & $\begin{array}{l}2.00 \\
(1.58,2.53)\end{array}$ & 0.20 & $\begin{array}{l}0.85 \\
(0.68,1.05)\end{array}$ & 0.85 & $\begin{array}{l}0.59 \\
(0.39,0.91)\end{array}$ & 0.15 & $\begin{array}{l}1.40 \\
(0.95,2.05)\end{array}$ & 0.26 & $\begin{array}{l}1.23 \\
(1.01,1.48)\end{array}$ & 0.45 \\
\hline $\begin{array}{l}\mathrm{UC}+ \\
\mathrm{MIBI}\end{array}$ & $\begin{array}{l}1.05 \\
(0.81,1.37)\end{array}$ & 0.94 & $\begin{array}{l}0.93 \\
(0.74,1.19)\end{array}$ & 0.94 & $\begin{array}{l}1.08 \\
(0.66,1.74)\end{array}$ & 0.87 & $\begin{array}{l}1.10 \\
(0.69,1.74)\end{array}$ & 0.78 & $\begin{array}{l}1.14 \\
(0.91,1.43)\end{array}$ & 0.68 \\
\hline $\begin{array}{l}\text { Note: AT } \\
\text { Impleme } \\
\text { usual ca } \\
\text { ceiling e } \\
\text { an actua }\end{array}$ & $\begin{array}{l}=\text { Addiction } \\
\text { tion \& Sust }\end{array}$ & $\begin{array}{l}\text { chnol } \\
\text { Iment }\end{array}$ & y Transfer C & $\begin{array}{l}\text { nter; } \mathrm{Cl} \\
\mathrm{l}=\mathrm{mot}\end{array}$ & onfidence ir & $\begin{array}{l}\text { rval; IC } \\
\text { wing-ba } \\
\text { ling eff } \\
\text {. Past } 2\end{array}$ & $\begin{array}{l}=\text { intracluste } \\
\text { sed brief inte } \\
\text { cts were exc } \\
3 \text { days subst }\end{array}$ & $\begin{array}{l}\text { Sorrelat } \\
\text { ention; } \\
\text { ded for } \\
\text { ice use }\end{array}$ & $\begin{array}{l}\text { n; ISF = } \\
\mathrm{R}=\text { odds rati } \\
\text { utcomes wit } \\
\text { reatment do€ }\end{array}$ & $\begin{array}{l}\text { UC = } \\
\text { put a } \\
\text { have }\end{array}$ \\
\hline
\end{tabular}

For days of primary substance use (see Fig. 4 for the distribution at follow-up), the ISF strategy had a significant impact on the effectiveness of the $\mathrm{MIBI}$, at least in terms of significantly decreasing the odds (odds ratio $[\mathrm{OR}]=0.11,95 \% \mathrm{Cl}=0.08,0.15, \mathrm{p}$ $=.01$ ) of clients using their primary substance daily during the 28 day follow-up period (i.e., ceiling effect). To help interpret the 
size of this effect, an OR of 0.11 is equivalent to an OR of 9.09 (1 / $0.11=9.09)$, which is considered a large effect (73). The ISF strategy increased the odds $(\mathrm{OR}=1.51)$ of clients being completely abstinent from their primary substance at follow-up, but this small effect was not statistically significant. Complementing the results shown in Table 7, Fig. 5 helps visualize the cross-level interaction (ATTC + ISF x UC + MIBI) between implementation condition (ATTC + ISF compared to ATTC) and intervention condition (UC + MIBI compared to $\mathrm{UC}$ ) on days of primary substance use.

The ISF strategy was not found to have a significant impact on the effectiveness of the MIBI (i.e., intervention effectiveness) for the other client outcome measures. However, there were significant effects for the ATTC + ISF strategy on clients' endorsement of problems related to their primary substance (i.e., problem recognition), which is important, yet distinct from the effectiveness of the MIBI (i.e., intervention effectiveness). Specifically, the ATTC + ISF strategy increased (a) the odds of client participants endorsing that their primary substance was associated with each of the 11 DSM- 5 symptoms (i.e., ceiling effect; $\mathrm{OR}=6.68,95 \% \mathrm{Cl}=5.39,8.28, \mathrm{p}=.01)$ and $(\mathrm{b})$ the number of the $11 \mathrm{DSM}-5$ symptoms endorsed for client participants without a ceiling/floor effect $(\mathrm{OR}=1.36,95 \% \mathrm{Cl}=1.09,1.68, \mathrm{p}=.01)$.

\section{Discussion}

We used a cluster-randomized, type 2 hybrid trial to simultaneously test the impact of the ISF strategy (as an adjunct to the ATTC strategy) on: (1) the integration of a MIBI for SUDs within HIV-CBOs across the United States, and (2) the effectiveness of the MIBI (as an adjunct to UC within HIV-CBOs). Contributing to the growing literature on the effectiveness of facilitationbased strategies (74-82) and the effectiveness of MIBIs for SUD within HIV service settings (18, 83-88), we found at least two findings of significance. First, we found evidence that the ISF strategy had a significant impact on improving the integration of the MIBI for SUDs, at least in terms of significantly improving the consistency and quality of MIBI implementation during the implementation phase (i.e., implementation effectiveness). Second, we found evidence that the ISF strategy had a significant impact on improving the effectiveness of the MIBI (i.e., intervention effectiveness), at least in terms of significantly decreasing the likelihood that client participants were using their primary substance daily during the follow-up period. However, our main findings also included null results. Indeed, we did not find support for our hypotheses that staff-level measures of the inner setting domain (i.e., implementation readiness, implementation climate, leadership engagement, tension-for-change) and characteristics of individuals domain (i.e., motivational interviewing experience, personal recovery status), two of the key CFIR domains (15), moderated the impact of the ISF strategy. Additionally, we did not find support for our hypotheses that the ISF strategy would significantly decrease time-to-proficiency and significantly increase level-of-sustainment. Organized in chronological order along the EPIS continuum (16), below we discuss the limitations, generalizability, and implications of our findings $(25,26)$.

In terms of time-to-proficiency, which was the project's preparation phase outcome, we did not find evidence supporting our hypotheses. However, we believe the potential for the ISF strategy to decrease time-to-proficiency was limited by requiring MIBI staff to demonstrate proficiency before they were allowed to help implement/test the project's MIBI for SUDs and/or instructing MIBI staff to demonstrate MIBI proficiency sometime before the beginning of the project's implementation phase, rather than as soon as possible. As such, our findings may or may not generalize to: (a) contexts in which demonstration of MIBI proficiency is required before staff are allowed to implement with clients and there is a stronger justification for staff demonstrating MIBI proficiency as soon as possible (e.g., fee-for-service contexts), and/or (b) contexts in which demonstration of MIBI proficiency is not required before staff are allowed to implement with clients. In terms of implications, our findings advance knowledge regarding the preparation of staff to implement a MIBI for SUDs, as well as highlight the need for research experimentally testing the extent to which strategies minimize the time to complete key activities (89) and the extent to which the impact of these strategies is significantly moderated by one or more constructs hypothesized to be important (e.g., implementation readiness, implementation climate, leadership engagement) (15).

Consistent with our time-to-proficiency findings, we did not find evidence to support our moderation-focused hypotheses regarding the impact of the ISF strategy on implementation effectiveness (i.e., the consistency and quality of implementation). We did, however, find evidence that the ISF strategy significantly improved the average level of implementation effectiveness

Page 19/31 
achieved by MIBI staff. A potential limitation of this finding is that MIBI staff were asked to limit the number of MIBIs implemented to three per month. This was done to help increase the likelihood that the monthly performance feedback and group consultation provided as part of the ATTC strategy could have an impact on MIBI quality, which is important given that implementation effectiveness is defined as the both the consistency (e.g., the number of MIBIs implemented) and quality (e.g., the adherence and competence to the MIBI protocol) of implementation $(14,20,21)$. Although we believe this approach was well-justified, our finding may not generalize to less controlled contexts and/or contexts in which the quality component of implementation effectiveness is not using the ITRS to measure MIBI quality. Nonetheless, a key implication of this finding is that the ISF strategy was a promising adjunct to the ATTC strategy, at least for improving the implementation of our project's MIBI for SUDs within HIV-CBOs. Thus, it is recommended that intermediary/purveyor organizations seeking to improve the integration of a MIBI for SUD within HIV-CBOs, such as the AIDS Education \& Training Center (AETC) network (90), consider use of the ATTC + ISF strategy for such efforts.

Consistent with prior research highlighting that implementation matters (91)(92) we found that in addition to significantly improving implementation effectiveness, the ISF strategy significantly improved intervention effectiveness. Notwithstanding the importance of this finding, it is important to note the ISF strategy's impact on the effectiveness of the project's MIBI for SUDs was limited to a single client outcome, days of primary substance use. Relatedly, days of primary substance use, as well as the other client outcome measures (e.g., times engaging in risky behaviors, days of missed HIV medication), were based on client self-report and limited to a 4-week follow-up period. We believe, however, blinding follow-up staff to all condition assignments and blinding client participants to HIV-CBO condition assignment helped minimize the extent to which biases associated with these limitations differ between conditions. To the best of our knowledge, we are the first to have experimentally tested the impact of an implementation strategy on intervention effectiveness, which is distinct from our prior implementation research that tested the impact of an implementation strategy on client outcomes (93). Thus, the generalizability of our findings may need to be limited to contexts similar to our current study. Similar to the implication associated with the impact of the ISF strategy on implementation effectiveness, the key implication of this finding is that future efforts to improve the integration of MIBIs for SUDs within HIV-CBOs, both implementation research and implementation practice (e.g., efforts conducted by the AETCs), should consider use of the ATTC + ISF strategy. Finally, Foy et al. (94) noted "If studies evaluating the effects of implementation intervention are to be of relevance to policy and practice, they should have end-points related to evidence-based processes of care, patient outcomes or population outcomes." Thus, another implication of our finding is the need for more type 2 hybrid trials that enable tests of impact on intervention effectiveness (i.e., the effectiveness of the clinical intervention), which is arguably one of the most relevant end-points of all.

Although level-of-sustainment is not possible without some level of implementation effectiveness occurring first, level-ofsustainment is another end-point of significant relevance (95-97). Thus, it is significant to note that: (a) we did not find support for our hypotheses related to level-of-sustainment (the ISF strategy would have an impact on level-of-sustainment, with its impact being moderated by one or more staff-level measures), and (b) the average level-of-sustainment was not only similar between conditions, but was relatively low (i.e., only 3 MIBIs during the 6-month sustainment period). The key limitation associated with this finding is level-of-sustainment was based on self-report from MIBI staff. Although it does not appear that self-report led to MIBI staff overestimating their level-of-sustainment, our level-of-sustainment measured also was limited by not being able to measure the extent to which MIBIs were implemented with quality, which may have been possible given the ISF strategy's impact on implementation effectiveness during the project's implementation phase. Conservatively, the generalizability of our findings should be limited to efforts to testing the impact of the ISF strategy as an adjunct to the ATTC strategy and/or the level-of-sustainment of a MIBI for SUDs within HIV-CBOs. However, we believe our finding generalize more broadly to research that has advanced knowledge regarding sustainment $(98,99)$. Arguably, sustainment is one of the most important outcomes to identify effective strategies for, especially given that the lack of sustainment minimizes the return-oninvestments for resources expended during prior phases along the EPIS continuum (e.g., exploration phase, preparation phase, implementation phase) (16). Thus, a key implication is that future research is needed to test strategies that can significantly improve both the relative effectiveness of the ATTC + ISF strategy on level-of-sustainment, as well as the extent to which the ATTC + ISF strategy improves the absolute level-of-sustainment. 


\section{Conclusions}

Although the ATTC strategy was found to be sufficient for the preparation of HIV-CBO staff to implement a MIBI for SUDs, the ISF strategy was found to be an effective adjunct to the ATTC strategy in terms of both implementation effectiveness (i.e., the consistency and quality of implementation during the implementation phase) and intervention effectiveness (i.e., the effectiveness of the MIBI for SUDs). Based on these findings, we conclude that future implementation research and practice focused on integrating a MIBI for SUD within HIV-CBOs should consider use of the ATTC + ISF strategy. However, given the ISF strategy did not have a significant impact on level-of-sustainment, which was similarly low in both implementation conditions, we also conclude that future efforts should seek to enhance the ATTC + ISF strategy via strategies focused on improving levelof-sustainment during the sustainment phase.

\section{Abbreviations}

$\begin{array}{ll}\text { AETC } & \text { AIDS Education \& Training Center } \\ \text { ATTC } & \text { Addiction Technology Transfer Center } \\ \text { CBO } & \text { community-based organization } \\ \text { CFIR } & \text { Consolidated Framework for Implementation Research } \\ \text { EPIS } & \text { Exploration-Preparation-Implementation-Sustainment } \\ \text { IRB } & \text { institutional review board } \\ \text { ISF } & \text { Implementation \& Sustainment Facilitation } \\ \text { ITRS } & \text { Independent Tape Rater Scale } \\ \text { MIBI } & \text { motivational interviewing-based brief intervention } \\ \text { NIDA } & \text { National Institute on Drug Abuse } \\ \text { PWH } & \text { people with HIV } \\ \text { SAT2HIV } & \text { Substance Abuse Treatment to HIV care } \\ \text { SBIRT } & \text { screening, brief intervention, and referral to treatment } \\ \text { SUD } & \text { substance use disorder } \\ \text { UC } & \text { usual care } \\ \text { ZOIB } & \text { zero-and-one inflated beta }\end{array}$

\section{Declarations}

Ethics Approval and Consent to Participate

The current study was conducted under the auspices of RTI International's institutional review board.

Consent for Publication

Not applicable. 
Availability of Data and Material

Upon reasonable request, which should be made to the corresponding author, study data or materials may be made available.

Competing Interests

None.

Funding

This work was supported by the National Institute on Drug Abuse (R01DA038146; PI Garner).

Authors' Contributions

Conception and design of the work: BG, HG, MC, SM, JF, KS, DV, EB, AT, and ST. Acquisition, analysis or interpretation of data: $B G, H G, M C, S M, J F, M R, K S, D V, M B, E B, A T$, and ST. Creation of new software used in the work: BG, CG, EB, and AT. Drafted the work or substantively revised it: BG, HG, MC, SM, JF, MB, EB, AT, and ST. In addition to having approved the submitted version, all authors have agreed to (a) be personally accountable for the author's own contributions and (b) ensure that questions related to the accuracy or integrity of any part of the work, even ones in which the author was not personally involved, are appropriately investigated, resolved, and the resolution documented in the literature.

Acknowledgments

The content is solely the responsibility of the authors and does not necessarily represent the official views of the government. The authors acknowledge that this project would not have been possible without both the participation and collaboration of the project's 39 organizations and their dedicated staff, as well as the participation of the organization's client participants. Additionally, this project would not have been possible without the assistance of the following: Tracy Karvinen, Traci Rieckmann, Matthew Orndorff, David Kaiser, Mark Zehner, and Marianne Kluckmann.

\section{References}

1. Gaynes BN, Pence BW, Eron JJ, Jr., Miller WC. Prevalence and comorbidity of psychiatric diagnoses based on reference standard in an HIV+ patient population. Psychosom Med. 2008;70(4):505-11. doi: 10.1097/PSY.0b013e31816aa0cc.

2. Lucas GM, Cheever LW, Chaisson RE, Moore RD. Detrimental effects of continued illicit drug use on the treatment of HIV-1 infection. J Acquir Immune Defic Syndr. 2001;27(3):251-9.

3. Arnsten JH, Demas PA, Grant RW, Gourevitch MN, Farzadegan H, Howard AA, et al. Impact of active drug use on antiretroviral therapy adherence and viral suppression in HIV-infected drug users. J Gen Intern Med. 2002;17(5):377-81.

4. King WD, Larkins S, Hucks-Ortiz C, Wang PC, Gorbach PM, Veniegas R, et al. Factors associated with HIV viral load in a respondent driven sample in Los Angeles. AIDS Behav. 2009;13(1):145-53. doi: 10.1007/s10461-007-9337-1.

5. Azar MM, Springer SA, Meyer JP, Altice FL. A systematic review of the impact of alcohol use disorders on HIV treatment outcomes, adherence to antiretroviral therapy and health care utilization. Drug Alcohol Depend. 2010;112(3):178-93. doi: 10.1016/j.drugalcdep.2010.06.014.

6. Friedman MS, Marshal MP, Stall R, Kidder DP, Henny KD, Courtenay-Quirk C, et al. Associations between substance use, sexual risk taking and HIV treatment adherence among homeless people living with HIV. AIDS Care. 2009;21(6):692-700. doi: 10.1080/09540120802513709.

7. Hendershot CS, Stoner SA, Pantalone DW, Simoni JM. Alcohol use and antiretroviral adherence: review and meta-analysis. J Acquir Immune Defic Syndr. 2009;52(2):180-202. doi: 10.1097/QAl.0b013e3181b18b6e.

8. Malta M, Strathdee SA, Magnanini MM, Bastos FI. Adherence to antiretroviral therapy for human immunodeficiency virus/acquired immune deficiency syndrome among drug users: a systematic review. Addiction. 2008;103(8):1242-57. doi: 10.1111/j.1360-0443.2008.02269.x.

Page 22/31 
9. Palepu A, Tyndall M, Yip B, O'Shaughnessy MV, Hogg RS, Montaner JS. Impaired virologic response to highly active antiretroviral therapy associated with ongoing injection drug use. J Acquir Immune Defic Syndr. 2003;32(5):522-6.

10. Hutton HE, Lesko CR, Li X, Thompson CB, Lau B, Napravnik S, et al. Alcohol use patterns and subsequent sexual behaviors among women, men who have sex with men and men who have sex with women engaged in routine HIV care in the United States. AIDS Behav. 2019;23(6):1634-46. doi: 10.1007/s10461-018-2337-5.

11. Satre DD, Sarovar V, Leyden W, Hare CB, Catz SL, Bryant KJ, et al. Association between changes in alcohol consumption and subsequent antiretroviral medication adherence, HIV viral control, and condomless sex. AIDS Behav. 2019.

12. Hartzler B, Dombrowski JC, Crane HM, Eron JJ, Geng EH, Christopher Mathews W, et al. Prevalence and predictors of substance use disorders among HIV care enrollees in the United States. AIDS Behav. 2017;21(4):1138-48. doi: 10.1007/s10461-016-1584-6.

13. U.S. Department of Health and Human Services, Health Resources and Services Administration, Bureau of Primary Health Care. Integrating HIV care, treatment \& prevention services into primary care - a toolkit for health centers. Rockville, Maryland: U.S. Department of Health and Human Services, 2017

14. Garner BR, Zehner M, Roosa MR, Martino S, Gotham HJ, Ball EL, et al. Testing the implementation and sustainment facilitation (ISF) strategy as an effective adjunct to the Addiction Technology Transfer Center (ATTC) strategy: study protocol for a cluster randomized trial. Addict Sci Clin Pract. 2017;12(1):32. doi: 10.1186/s13722-017-0096-7.

15. Damschroder LJ, Aron DC, Keith RE, Kirsh SR, Alexander JA, Lowery JC. Fostering implementation of health services research findings into practice: a consolidated framework for advancing implementation science. Implement Sci. 2009;4:50. doi: 10.1186/1748-5908-4-50.

16. Aarons GA, Hurlburt M, Horwitz SM. Advancing a conceptual model of evidence-based practice implementation in public service sectors. Adm Policy Ment Health. 2011;38(1):4-23. doi: 10.1007/s10488-010-0327-7.

17. Aharonovich E, Hatzenbuehler ML, Johnston B, O'Leary A, Morgenstern J, Wainberg ML, et al. A low-cost, sustainable intervention for drinking reduction in the HIV primary care setting. AIDS Care. 2006;18(6):561-8. doi: 10.1080/09540120500264134.

18. Aharonovich E, Greenstein E, O'Leary A, Johnston B, Seol SG, Hasin DS. HealthCall: technology-based extension of motivational interviewing to reduce non-injection drug use in HIV primary care patients - a pilot study. AIDS Care. 2012;24(12):1461-9. doi: 10.1080/09540121.2012.663882.

19. Hasin DS, Aharonovich E, O'Leary A, Greenstein E, Pavlicova M, Arunajadai S, et al. Reducing heavy drinking in HIV primary care: a randomized trial of brief intervention, with and without technological enhancement. Addiction. 2013;108(7):123040. doi: $10.1111 /$ add.12127.

20. Klein KJ, Sorra JS. The challenge of innovation implementation. Acad Manage Rev. 1996;21(4):1055-80. doi: $10.2307 / 259164$.

21. Klein KJ, Conn AB, Sorra JS. Implementing computerized technology: an organizational analysis. J Appl Psychol. 2001;86(5):811-24.

22. Helfrich CD, Weiner BJ, McKinney MM, Minasian L. Determinants of implementation effectiveness: adapting a framework for complex innovations. Med Care Res Rev. 2007;64(3):279-303. doi: 10.1177/1077558707299887.

23. Weiner BJ, Lewis MA, Linnan LA. Using organization theory to understand the determinants of effective implementation of worksite health promotion programs. Health Educ Res. 2009;24(2):292-305. doi: 10.1093/her/cyn019.

24. Garner BR, Gotham HJ, Tueller SJ, Ball EL, Kaiser D, Stilen P, et al. Testing the effectiveness of a motivational interviewingbased brief intervention for substance use as an adjunct to usual care in community-based AIDS service organizations: study protocol for a multisite randomized controlled trial. Addict Sci Clin Pract. 2017;12(1):31. doi: 10.1186/s13722-0170095-8.

25. Campbell MK, Piaggio G, Elbourne DR, Altman DG, Group C. Consort 2010 statement: Extension to cluster randomised trials. BMJ. 2012;345:e5661. doi: 10.1136/bmj.e5661. 
26. Pinnock H, Barwick M, Carpenter CR, Eldridge S, Grandes G, Griffiths CJ, et al. Standards for Reporting Implementation Studies (StaRI) Statement. BMJ. 2017;356:i6795. doi: 10.1136/bmj.i6795.

27. National Institute of Standards and Technology, Information Technology Library. FIPS Publications. Washington, DC: National Institute of Standards and Technology; 2007. updated October 16, 2015; cited 2017 January 24.

28. Kotz D, Spigt M, Arts IC, Crutzen R, Viechtbauer W. Use of the stepped wedge design cannot be recommended: a critical appraisal and comparison with the classic cluster randomized controlled trial design. J Clin Epidemiol. 2012;65(12):124952 .

29. Mdege ND, Man MS, Taylor CA, Torgerson DJ. There are some circumstances where the stepped-wedge cluster randomized trial is preferable to the alternative: no randomized trial at all. Response to the commentary by Kotz and colleagues. J Clin Epidemiol. 2012;65(12):1253.

30. Kotz D, Spigt M, Arts IC, Crutzen R, Viechtbauer W. Researchers should convince policy makers to perform a classic cluster randomized controlled trial instead of a stepped wedge design when an intervention is rolled out. J Clin Epidemiol. 2012;65(12):1255.

31. Curran GM, Bauer M, Mittman B, Pyne JM, Stetler C. Effectiveness-implementation hybrid designs: combining elements of clinical effectiveness and implementation research to enhance public health impact. Med Care. 2012;50(3):217-26. doi: 10.1097/MLR.0b013e3182408812.

32. Landes SJ, McBain SA, Curran GM. An introduction to effectiveness-implementation hybrid designs. Psychiatry Res. 2019;283:112630.

33. Collins LM, Murphy SA, Strecher V. The multiphase optimization strategy (MOST) and the sequential multiple assignment randomized trial (SMART): new methods for more potent eHealth interventions. Am J Prev Med. 2007;32(5 Suppl):S112-8. doi: 10.1016/j.amepre.2007.01.022.

34. Dziak JJ, Nahum-Shani I, Collins LM. Multilevel factorial experiments for developing behavioral interventions: power, sample size, and resource considerations. Psychol Methods. 2012;17(2):153-75. doi: 10.1037/a0026972.

35. DiClemente CC, Corno CM, Graydon MM, Wiprovnick AE, Knoblach DJ. Motivational interviewing, enhancement, and brief interventions over the last decade: A review of reviews of efficacy and effectiveness. Psychol Addict Behav. 2017;31(8):862-87. doi: 10.1037/adb0000318.

36. Kaner EF, Dickinson HO, Beyer F, Pienaar E, Schlesinger C, Campbell F, et al. The effectiveness of brief alcohol interventions in primary care settings: a systematic review. Drug Alcohol Rev. 2009;28(3):301-23. doi: 10.1111/j.1465-

3362.2009.00071.x.

37. Lundahl BW, Kunz C, Brownell C, Tollefson D, Burke BL. A meta-analysis of motivational interviewing: twenty-five years of empirical studies. Res Soc Work Pract. 2010;20(2):137-60. doi: 10.1177/1049731509347850.

38. McQueen J, Howe TE, Allan L, Mains D, Hardy V. Brief interventions for heavy alcohol users admitted to general hospital wards. Cochrane Database Syst Rev. 2011;8(8):CD005191. doi: 10.1002/14651858.CD005191.pub3.

39. Stewart JS. A critical appraisal of motivational interviewing within the field of alcohol misuse. J Psychiatr Ment Health Nurs. 2012;19(10):933-8.

40. Baker A, Turner A, Kay-Lambkin FJ, Lewin TJ. The long and the short of treatments for alcohol or cannabis misuse among people with severe mental disorders. Addict Behav. 2009;34(10):852-8.

41. Baker AL, Hides L, Lubman DI. Treatment of cannabis use among people with psychotic or depressive disorders: a systematic review. J Clin Psychiatry. 2010;71(3):247-54. doi: 10.4088/JCP.09r05119gry.

42. Dennhardt AA, Murphy JG. Prevention and treatment of college student drug use: A review of the literature. Addict Behav. 2013;38(10):2607-18. doi: 10.1016/j.addbeh.2013.06.006.

43. Miller WR, Yahne CE, Moyers TB, Martinez J, Pirritano M. A randomized trial of methods to help clinicians learn motivational interviewing. J Consult Clin Psychol. 2004;72(6):1050-62. doi: 10.1037/0022-006x.72.6.1050.

44. Madson MB, Loignon AC, Lane C. Training in motivational interviewing: a systematic review. J Subst Abuse Treat. 2009;36(1):101-9. doi: 10.1016/j.jsat.2008.05.005.

Page 24/31 
45. Martino S. Strategies for training counselors in evidence-based treatments. Addict Sci Clin Pract. 2010;5(2):30-9.

46. Barwick MA, Bennett LM, Johnson SN, McGowan J, Moore JE. Training health and mental health professionals in motivational interviewing: A systematic review. Children and Youth Services Review. 2012;34(9):1786-95. doi: 10.1016/j.childyouth.2012.05.012.

47. de Roten Y, Zimmermann G, Ortega D, Despland JN. Meta-analysis of the effects of MI training on clinicians' behavior. J Subst Abuse Treat. 2013;45(2):155-62. doi: 10.1016/j.jsat.2013.02.006.

48. Darnell D, Dunn C, Atkins D, Ingraham L, Zatzick D. A randomized evaluation of motivational interviewing training for mandated implementation of alcohol screening and brief intervention in trauma centers. J Subst Abuse Treat. 2016;60:3644. doi: 10.1016/j.jsat.2015.05.010.

49. Madson MB, Villarosa-Hurlocker MC, Schumacher JA, Williams DC, Gauthier JM. Motivational interviewing training of substance use treatment professionals: A systematic review. Subst Abus. 2019;40(1):43-51. doi: 10.1080/08897077.2018.1475319.

50. Addiction Technology Transfer Center Network. cited 2020 March 5 Available from: https://attcnetwork.org/.

51. Proctor E, Hooley C, Morse A, McCrary S, Kim H, Kohl PL. Intermediary/purveyor organizations for evidence-based interventions in the US child mental health: characteristics and implementation strategies. Implement Sci. 2019;14(1):3. doi: 10.1186/s13012-018-0845-3.

52. Proctor EK, Landsverk J, Aarons G, Chambers D, Glisson C, Mittman B. Implementation research in mental health services: an emerging science with conceptual, methodological, and training challenges. Adm Policy Ment Health. 2009;36(1):2434. doi: 10.1007/s10488-008-0197-4.

53. Harvey G, Loftus-Hills A, Rycroft-Malone J, Titchen A, Kitson A, McCormack B, et al. Getting evidence into practice: the rol and function of facilitation. J Adv Nurs. 2002;37(6):577-88.

54. Stetler CB, Legro MW, Rycroft-Malone J, Bowman C, Curran G, Guihan M, et al. Role of "external facilitation" in implementation of research findings: a qualitative evaluation of facilitation experiences in the Veterans Health Administration. Implement Sci. 2006;1:23. doi: 10.1186/1748-5908-1-23.

55. Kitson AL, Rycroft-Malone J, Harvey G, McCormack B, Seers K, Titchen A. Evaluating the successful implementation of evidence into practice using the PARiHS framework: Theoretical and practical challenges. Implement Sci. 2008;3(1):1.

56. Kauth MR, Sullivan G, Blevins D, Cully JA, Landes RD, Said Q, et al. Employing external facilitation to implement cognitive behavioral therapy in VA clinics: a pilot study. Implement Sci. 2010;5:75. doi: 10.1186/1748-5908-5-75.

57. Liddy C, Hogg W, Russell G, Wells G, Armstrong CD, Akbari A, et al. Improved delivery of cardiovascular care (IDOCC) through outreach facilitation: study protocol and implementation details of a cluster randomized controlled trial in primary care. Implement Sci. 2011;6(1):110.

58. Baskerville NB, Liddy C, Hogg W. Systematic review and meta-analysis of practice facilitation within primary care settings. The Annals of Family Medicine. 2012;10(1):63-74.

59. Cully JA, Armento ME, Mott J, Nadorff MR, Naik AD, Stanley MA, et al. Brief cognitive behavioral therapy in primary care: a hybrid type 2 patient-randomized effectiveness-implementation design. Implement Sci. 2012;7:64. doi: 10.1186/17485908-7-64.

60. Seers K, Cox K, Crichton NJ, Edwards RT, Eldh AC, Estabrooks CA, et al. FIRE (Facilitating Implementation of Research Evidence): a study protocol. Implement Sci. 2012;7(1):25. doi: 10.1186/1748-5908-7-25.

61. Gustafson DH, Quanbeck AR, Robinson JM, Ford JH, 2nd, Pulvermacher A, French MT, et al. Which elements of improvement collaboratives are most effective? A cluster-randomized trial. Addiction. 2013;108(6):1145-57. doi: 10.1111/add.12117.

62. Owen RR, Drummond KL, Viverito KM, Marchant K, Pope SK, Smith JL, et al. Monitoring and managing metabolic effects of antipsychotics: a cluster randomized trial of an intervention combining evidence-based quality improvement and external facilitation. Implement Sci. 2013;8(1):120. doi: 10.1186/1748-5908-8-120.

Page 25/31 
63. Parchman ML, Noel PH, Culler SD, Lanham HJ, Leykum LK, Romero RL, et al. A randomized trial of practice facilitation to improve the delivery of chronic illness care in primary care: initial and sustained effects. Implement Sci. 2013;8:93. doi: 10.1186/1748-5908-8-93.

64. Wagner CC, Ingersoll KS. Motivational interviewing in groups. Guilford Press; 2012.

65. Mackinnon DP. Integrating mediators and moderators in research design. Res Soc Work Pract. 2011;21(6):675-81. doi: 10.1177/1049731511414148.

66. American Psychiatric Association. Diagnostic and statistical manual of mental disorders: DSM-5. Washington, DC: American Psychiatric Association; 2013.

67. Garner BR, Gotham HJ, Tueller SJ, Ball E, Kaiser D, Stilen P, et al. Testing the effectiveness of a motivational interviewingbased brief intervention for substance use as an adjunct to usual care in community-based AIDS service organizations: Study protocol for a multisite randomized controlled trial. Addict Sci Clin Pract. 2017;12(1):31.

68. Raudenbush SW, et al. Optimal design software for multi-level and longitudinal research (Version 3.01) [Software]. 2011.

69. Stout RL, Wirtz PW, Carbonari JP, Del Boca FK. Ensuring balanced distribution of prognostic factors in treatment outcome research. J Stud Alcohol Suppl. 1994;12(Suppl):70-5. doi: 10.15288/jsas.1994.s12.70.

70. Charpentier PA. Urn Randomization Program gRand [computer program]. 1.10th ed. New Haven: Yale University; 2003.

71. Sealed Envelope. Randomisation and online databases for clinical trials. n.d. Available from: https://www.sealedenvelope.com/.

72. Liu F, Kong Y. zoib: An R package for bayesian inference for beta regression and zero/one inflated beta regression. The $\mathrm{R}$ Journal. 2015;7(2):34-51.

73. Chen $\mathrm{H}$, Cohen $\mathrm{P}$, Chen $\mathrm{S}$. How big is a big odds ratio? Interpreting the magnitudes of odds ratios in epidemiological studies. Communications in Statistics-Simulation and Computation ${ }^{8}$, 2010;39(4):860-4.

74. Kilbourne AM, Almirall D, Goodrich DE, Lai Z, Abraham KM, Nord KM, et al. Enhancing outreach for persons with serious mental illness: 12-month results from a cluster randomized trial of an adaptive implementation strategy. Implement Sci. 2014;9(1):163. doi: 10.1186/s13012-014-0163-3.

75. Kirchner JE, Ritchie MJ, Pitcock JA, Parker LE, Curran GM, Fortney JC. Outcomes of a partnered facilitation strategy to implement primary care-mental health. J Gen Intern Med. 2014;29 Suppl 4:904-12. doi: 10.1007/s11606-014-3027-2.

76. Chinman M, Acosta J, Ebener P, Malone PS, Slaughter ME. Can implementation support help community-based settings better deliver evidence-based sexual health promotion programs? A randomized trial of Getting To Outcomes ${ }^{\circledR}$. Implement Sci. 2015);11(1):78.

77. Jones J, Wyse R, Finch M, Lecathelinais C, Wiggers J, Marshall J, et al. Effectiveness of an intervention to facilitate the implementation of healthy eating and physical activity policies and practices in childcare services: a randomised controlled trial. Implement Sci. 2015;10(1):147. doi: 10.1186/s13012-015-0340-z.

78. Kilbourne AM, Goodrich DE, Lai Z, Almirall D, Nord KM, Bowersox NW, et al. Reengaging veterans with serious mental illness into care: Preliminary results from a national randomized trial. Psychiatr Serv. 2015;66(1):90-3.

79. Lessard S, Bareil C, Lalonde L, Duhamel F, Hudon E, Goudreau J, et al. External facilitators and interprofessional facilitation teams: A qualitative study of their roles in supporting practice change. Implement Sci. 2015;11(1):97.

80. Liddy C, Hogg W, Singh J, Taljaard M, Russell G, Deri Armstrong C, et al. A real-world stepped wedge cluster randomized trial of practice facilitation to improve cardiovascular care. Implement Sci. 2015;10(1):150. doi: 10.1186/s13012-0150341-y.

81. Chinman M, McCarthy S, Hannah G, Byrne TH, Smelson DA. Using getting to outcomes to facilitate the use of an evidencebased practice in VA homeless programs: A cluster-randomized trial of an implementation support strategy. Implement Sci. 2017;12(1):34.

82. Seers K, Rycroft-Malone J, Cox K, Crichton N, Edwards RT, Eldh AC, et al. Facilitating Implementation of Research Evidence (FIRE): An international cluster randomised controlled trial to evaluate two models of facilitation informed by the 
Promoting Action on Research Implementation in Health Services (PARIHS) framework. Implement Sci. 2018;13(1):137. doi: 10.1186/s13012-018-0831-9.

83. Hasin DS, Aharonovich E, Greenstein E. HealthCall for the smartphone: Technology enhancement of brief intervention in HIV alcohol dependent patients. Addict Sci Clin Pract. 2014;9(1):5. doi: 10.1186/1940-0640-9-5.

84. Wray TB, Grin B, Dorfman L, Glynn TR, Kahler CW, Marshall BD, et al. Systematic review of interventions to reduce problematic alcohol use in men who have sex with men. Drug Alcohol Rev. 2016;35(2):148-57. doi: 10.1111/dar.12271.

85. Aharonovich E, Sarvet A, Stohl M, DesJarlais D, Tross S, Hurst T, et al. Reducing non-injection drug use in HIV primary care: A randomized trial of brief motivational interviewing, with and without HealthCall, a technology-based enhancement. J Subst Abuse Treat. 2017;74:71-9. doi: 10.1016/j.jsat.2016.12.009.

86. Scott-Sheldon LAJ, Carey KB, Johnson BT, Carey MP, Team MR. Behavioral Interventions Targeting Alcohol Use Among People Living with HIV/AIDS: A Systematic Review and Meta-Analysis. AIDS Behav. 2017;21(Suppl 2):126-43. doi: 10.1007/s10461-017-1886-3.

87. Haldane V, Legido-Quigley H, Chuah FLH, Sigfrid L, Murphy G, Ong SE, et al. Integrating cardiovascular diseases, hypertension, and diabetes with HIV services: a systematic review. AIDS Care. 2018;30(1):103-15. doi: 10.1080/09540121.2017.1344350.

88. Kahler CW, Pantalone DW, Mastroleo NR, Liu T, Bove G, Ramratnam B, et al. Motivational interviewing with personalized feedback to reduce alcohol use in HIV-infected men who have sex with men: A randomized controlled trial. J Consult Clin Psychol. 2018;86(8):645.

89. Saldana L, Chamberlain P, Wang W, Hendricks Brown C. Predicting program start-up using the stages of implementation measure. Adm Policy Ment Health. 2012;39(6):419-25. doi: 10.1007/s10488-011-0363-y.

90. AIDS Education \& Training Center Program National Coordinating Resource Center. cited 2010 March 5, Available from: https://aidsetc.org.

91. Durlak JA, DuPre EP. Implementation matters: a review of research on the influence of implementation on program outcomes and the factors affecting implementation. Am J Community Psychol. 2008;41(3-4):327-50. doi: 10.1007/s10464-008-9165-0.

92. Garner BR, Hunter SB, Funk RR, Griffin BA, Godley SH. Toward evidence-based measures of implementation: examining the relationship between implementation outcomes and client outcomes. J Subst Abuse Treat. 2016;67:15-21. doi: 10.1016/j.jsat.2016.04.006.

93. Garner BR, Godley SH, Dennis ML, Hunter B, Bair C, Godley MD. Using pay for performance to improve treatment implementation for adolescent substance use disorders: results from a cluster randomized trial. Arch Pediatr Adolesc Med. 2012;166:938-44. doi: 10.1007/archpediatrics.2012.802.

94. Foy R, Sales A, Wensing M, Aarons GA, Flottorp S, Kent B, et al. Implementation science: a reappraisal of our journal mission and scope. 2015.

95. Stirman SW, Kimberly J, Cook N, Calloway A, Castro F, Charns M. The sustainability of new programs and innovations: a review of the empirical literature and recommendations for future research. Implement Sci. 2012;7:17. doi: Artn 17Doi 10.1186/1748-5908-7-17.

96. Chambers DA, Glasgow RE, Stange KC. The dynamic sustainability framework: addressing the paradox of sustainment amid ongoing change. Implement Sci. 2013;8(1):117. doi: 10.1186/1748-5908-8-117.

97. Proctor E, Luke D, Calhoun A, McMillen C, Brownson R, McCrary S, et al. Sustainability of evidence-based healthcare: research agenda, methodological advances, and infrastructure support. Implement Sci. 2015;10(1):88. doi: 10.1186/s13012-015-0274-5.

98. Hunter SB, Han B, Slaughter ME, Godley SH, Garner BR. Associations between implementation characteristics and evidence-based practice sustainment: A study of the Adolescent Community Reinforcement Approach. Implement Sci. 2015;10(1):173. 
99. Hunter SB, Han B, Slaughter ME, Godley SH, Garner BR. Predicting evidence-based treatment sustainment: Results from a longitudinal study of the Adolescent-Community Reinforcement Approach. Implement Sci. 2017;12(1):75. doi:

10.1186/s13012-017-0606-8.

100. Martino S, Ball SA, Nich C, Frankforter TL, Carroll KM. Community program therapist adherence and competence in motivational enhancement therapy. Drug Alcohol Depend. 2008;96(1-2):37-48. doi: 10.1016/j.drugalcdep.2008.01.020.

101. McLellan AT, Kushner H, Metzger D, Peters R, Smith I, Grissom G, et al. The Fifth Edition of the Addiction Severity Index. J Subst Abuse Treat. 1992;9(3):199-213.

102. Shea CM, Jacobs SR, Esserman DA, Bruce K, Weiner BJ. Organizational readiness for implementing change: a psychometric assessment of a new measure. Implement Sci. 2014;9(1):7. doi: 10.1186/1748-5908-9-7.

103. Jacobs SR, Weiner BJ, Bunger AC. Context matters: measuring implementation climate among individuals and groups. Implement Sci. 2014;9:46. doi: 10.1186/1748-5908-9-46.

\section{Figures}

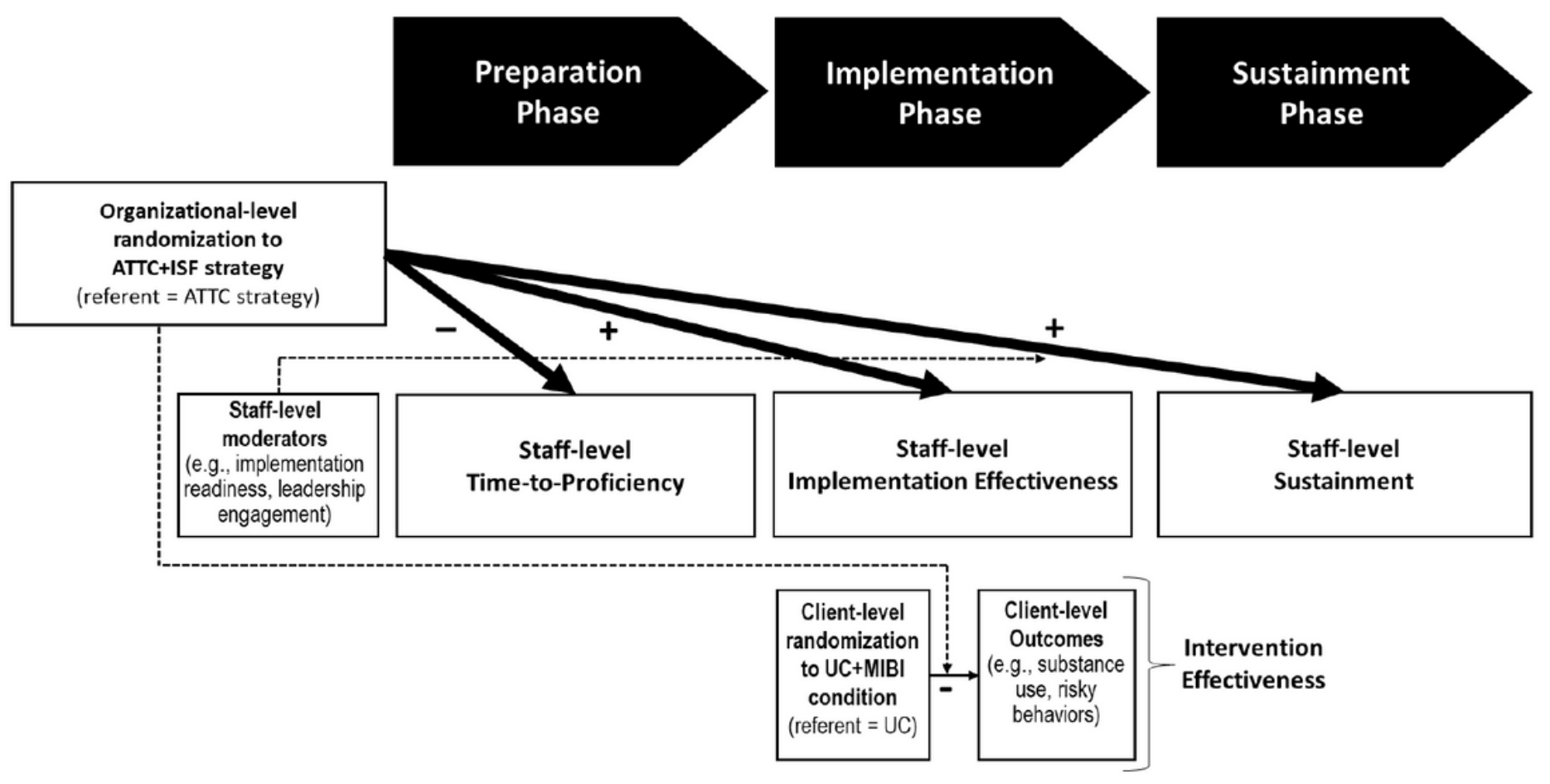

Figure 1

Aims and Hypotheses Note: ATTC = Addiction Technology Transfer Center; ISF Implementation \& Sustainment Facilitation; $\mathrm{MIBI}=$ motivational interviewing-based brief intervention; $\mathrm{UC}=$ usual care. Bolded lines indicate primary aim and hypotheses; thin line indicates other aim; dashed lines indicate hypothesized moderators. 


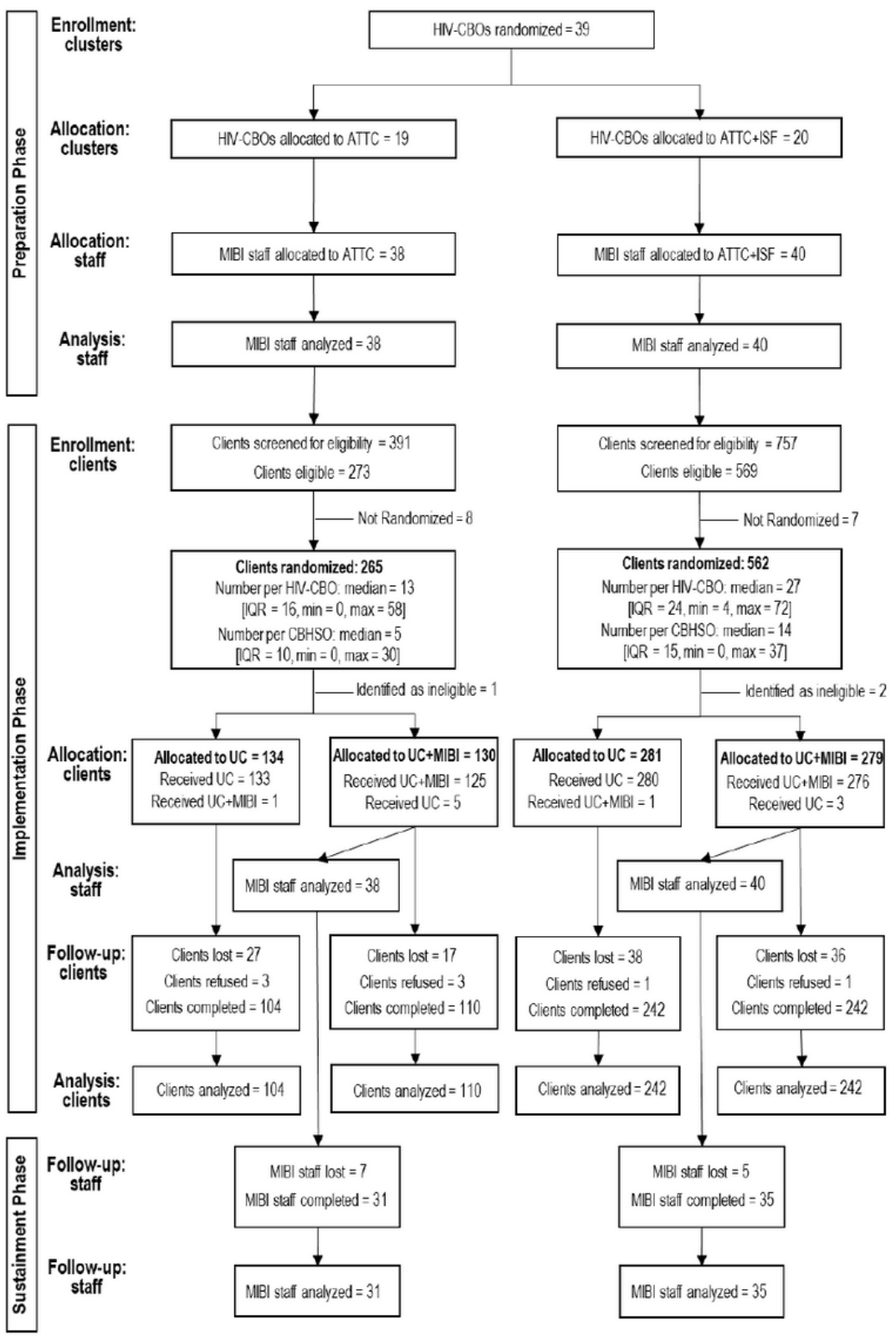

\section{Figure 2}

Participant Flow Note: ATTC = Addiction Technology Transfer Center; IQR = interquartile range; ISF Implementation \& Sustainment Facilitation; $\mathrm{MIBI}=$ motivational interviewing-based brief intervention; $\mathrm{UC}=$ usual care. 


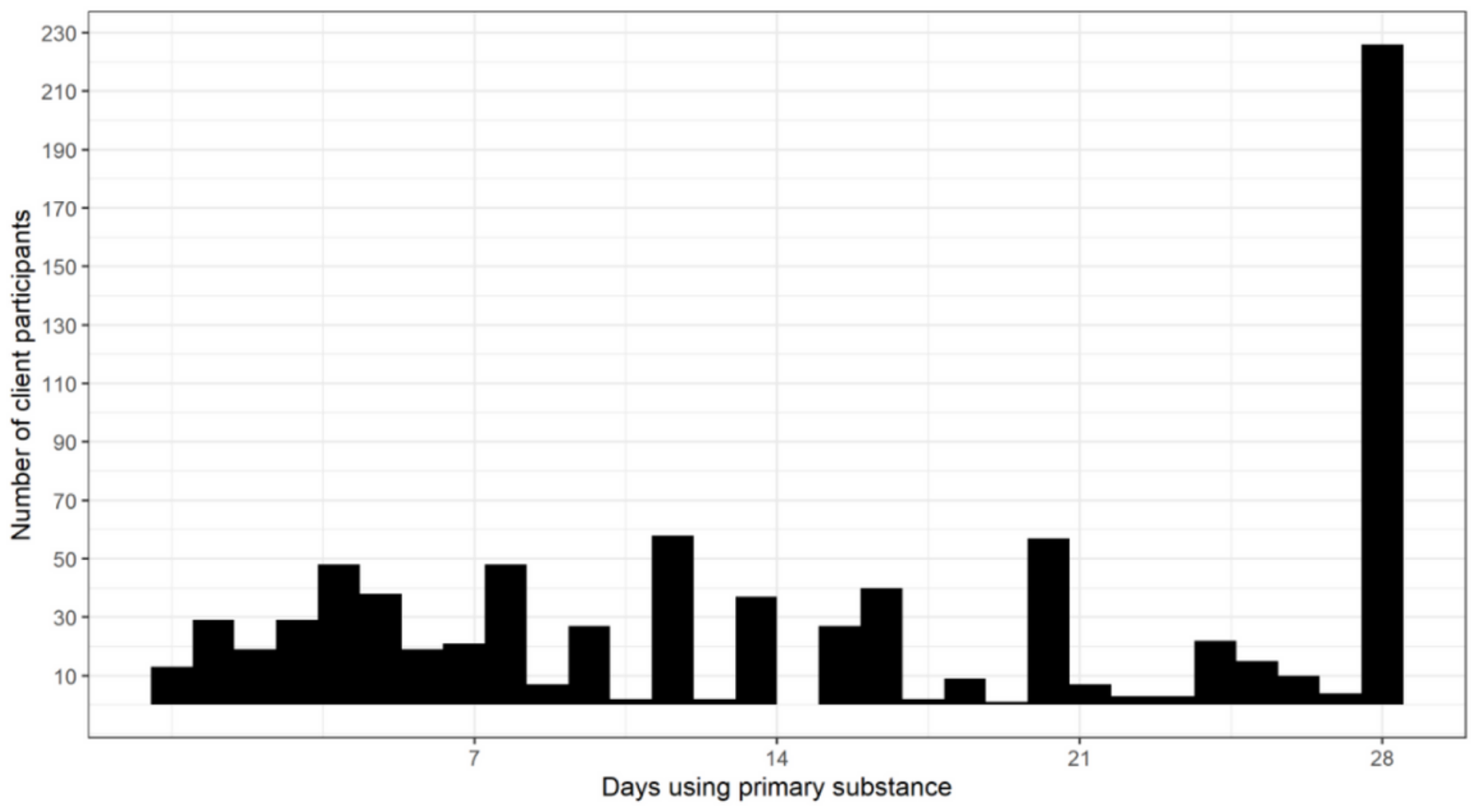

Figure 3

Baseline Distribution for Client's Days of Primary Substance Use

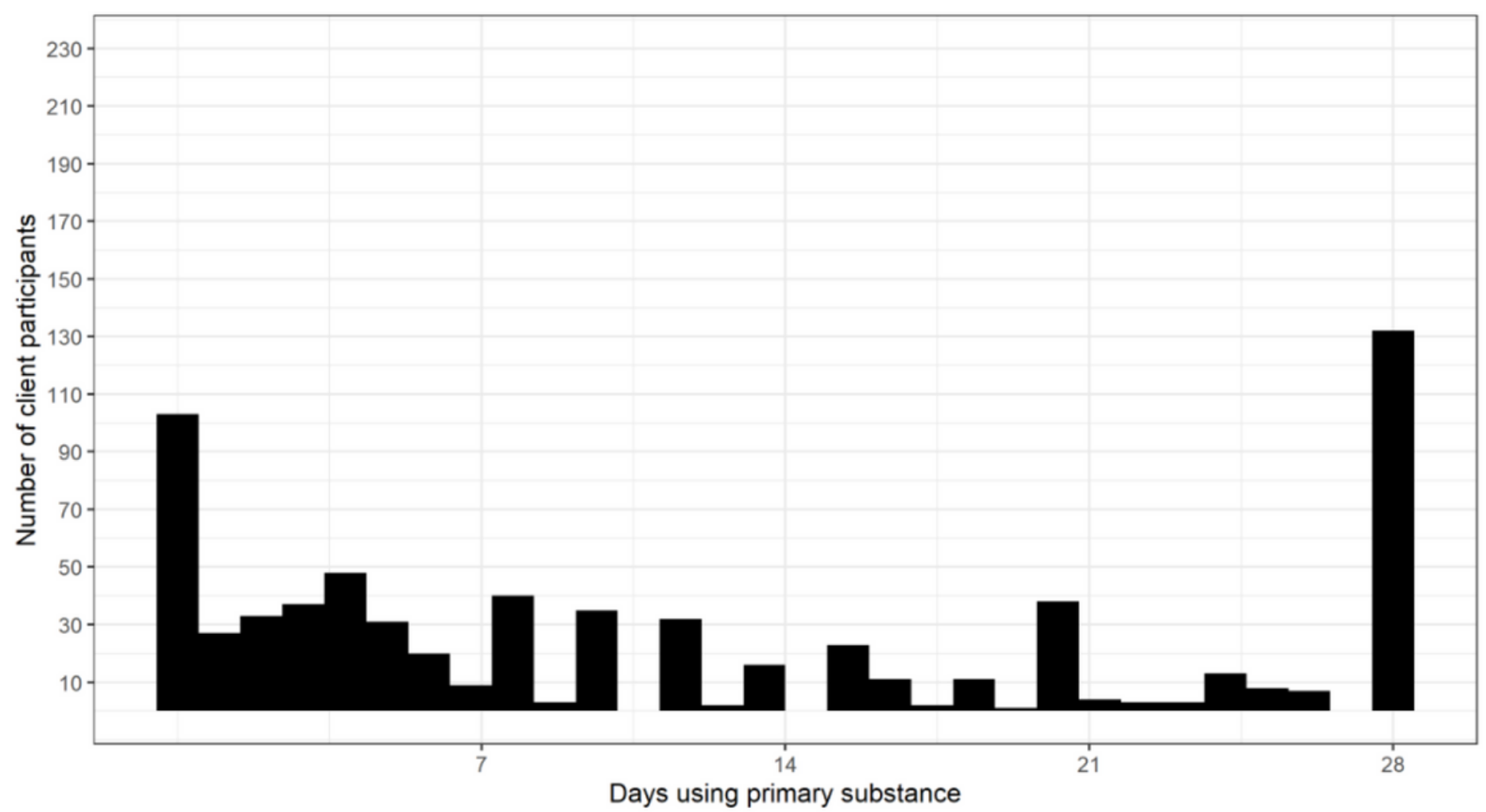

Figure 4 


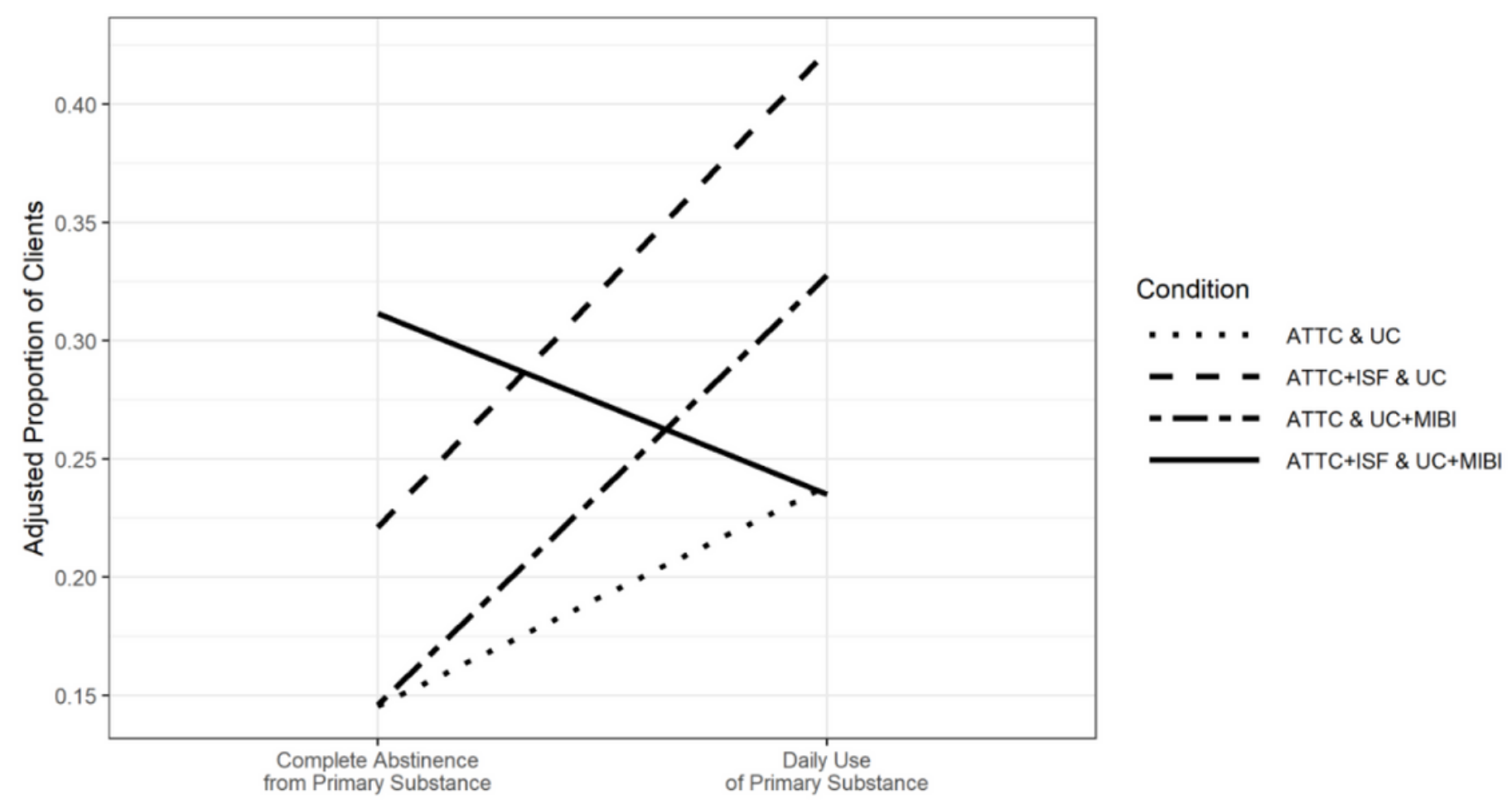

\section{Figure 5}

The Impact of the ISF Strategy on Intervention Effectiveness

\section{Supplementary Files}

This is a list of supplementary files associated with this preprint. Click to download.

- AdditionalFile2.pdf

- AdditionalFile1.pdf 